\title{
Sputtered $\mathrm{LiCoO}_{2}$ Cathode Materials for All-Solid-State Thin-Film Lithium Microbatteries
}

\author{
Christian M. Julien ${ }^{1, * \mathbb{D}}$, Alain Mauger ${ }^{1}$ and Obili M. Hussain ${ }^{2}$ \\ 1 Institut de Minéralogie, de Physique des Matériaux et de Cosmochimie (IMPMC), CNRS UMR 7590, \\ Campus Pierre et Marie Curie, Sorbonne Université, 4 place Jussieu, 75005 Paris, France \\ 2 Thin Films Laboratory, Department of Physics, Sri Venkateswara University, Tirupati 517502, India \\ * Correspondence: christian.julien@upmc.fr
}

Received: 20 July 2019; Accepted: 20 August 2019; Published: 22 August 2019

\begin{abstract}
This review article presents the literature survey on radio frequency (RF)-magnetron sputtered $\mathrm{LiCoO}_{2}$ thin films used as cathode materials in all-solid-state rechargeable lithium microbatteries. As the process parameters lead to a variety of texture and preferential orientation, the influence of the sputtering conditions on the deposition of $\mathrm{LiCoO}_{2}$ thin films are considered. The electrochemical performance is examined as a function of composition of the sputter $\mathrm{Ar} / \mathrm{O}_{2}$ gas mixture, gas flow rate, pressure, nature of substrate, substrate temperature, deposition rate, and annealing temperature. The state-of-the-art of lithium microbatteries fabricated by the rf-sputtering method is also reported.
\end{abstract}

Keywords: thin films; sputtering technique; lithium cobaltate; cathode material; lithium microbattery

\section{Introduction}

Rechargeable thin-film lithium microbatteries (LMBs) have been developed to power wearable electronic microdevices as a noise-free power source [1]. All-solid-state LMBs have attracted more and more interest due to safety and chemical stability issues of the solid electrolyte. The first microbattery made at Oak Ridge National Labs (ORNL) was integrated to complementary metal oxide semiconductor (CMOS) chips as a memory for the basic input/output system (BIOS) of computers [2-4]. Currently, there is an increasing demand for thin-film microbatteries. While the global Li-ion battery market is expected to surpass $\$ 77$ billion by 2024 , the thin-film batteries market is forecasted to reach $\$ 1.72$ billion [5]. Since the invention by the ORNL group, numerous studies have been devoted to the design and optimization of the best positive electrode material, which is the limiting element of a microbattery (i.e., the capacity delivered by the power source is governed by the material). In particular, $\mathrm{LiCoO}_{2}$ (LCO), which was identified as a promising candidate cathode material for Li-ion batteries (LIBs) [6], yields a practical specific capacity of $135 \mathrm{mAh} \mathrm{g}^{-1}$ and it shows a fast charge-discharge reaction in the potential range from $\sim 3.8 \mathrm{~V}$ (fully lithiated state) to $\sim 4.2 \mathrm{~V} \mathrm{vs.} \mathrm{Li}^{+} / \mathrm{Li}$ (charge state at $\mathrm{Li}_{0.5} \mathrm{CoO}_{2}$ ) [7].

Among the various physical deposition techniques, radio-frequency (RF) magnetron sputtering is a powerful method to prepare oxide thin-films by controlling their crystalline structure and surface roughness with a composition similar to that of the target material. Features that make rf-magnetron sputtering a suitable technique for all-solid-state batteries can be summarized as follows. This deposition method can operate in a reactive atmosphere at low pressure (0.1 to $10 \mathrm{~Pa}$ ). Using a high frequency of $13.56 \mathrm{MHz}$ to adequately ionize the gas, there are reduced arcing and charge-up effects. Finally, due to the highly accelerated particles arriving on the substrate (10 to $40 \mathrm{eV})$, the rf-sputtered coatings have superior adhesion compared with other techniques. In addition, the chamber can include the multiple targets needed for successive deposits during the manufacture of a microbattery. 
Various intercalation compounds such as thin-film cathodes for LMBs have been fabricated by rf-magnetron sputtering, i.e., $\mathrm{MoO}_{3}, \mathrm{~V}_{2} \mathrm{O}_{5}, \mathrm{LiMn}_{2} \mathrm{O}_{4}, \mathrm{LiCoO}_{2}, \mathrm{LifePO}_{4}, \mathrm{WO}_{3}$, etc. [8-11]. Actually, sputtered $\mathrm{LiCoO}_{2}$ films have become the most popular electrodes for thin-film microbatteries. The choice of this material comes from several reasons. (i) It has demonstrated high electrochemical performance due to its lamellar structure favorable for $\mathrm{Li}^{+}$ion pathway. (ii) $\mathrm{It}$ is a ternary compound whose synthesis is more easily controllable than other compound performers like $\mathrm{LiFePO}_{4}$ (LFP) and $\mathrm{LiNi}_{\mathrm{x}} \mathrm{Mn}_{\mathrm{y}} \mathrm{Co}_{1-\mathrm{x}-\mathrm{y}} \mathrm{O}_{2}$ (NMC). (iii) It has a higher voltage ( $>4 \mathrm{~V}$ vs. $\mathrm{Li}^{+} / \mathrm{Li}$ ) and delivers higher energy density than $\mathrm{LiFePO}_{4}$ olivine or $\mathrm{LiMn}_{2} \mathrm{O}_{4}$ spinel. (iv) The growth with preferential orientation for fast kinetics is relatively easy.

$\mathrm{LiCoO}_{2}$ (LCO) crystallizes in the rhombohedral structure (space group $R-3 m$ ) with atoms in the following Wykoff positions: $\mathrm{Co}$ in $3 a(0,0,0), \mathrm{Li}$ in $3 b\left(0,0, \frac{1}{2}\right)$ and $\mathrm{O}$ in $6 c$ sites $\left(0,0, \frac{1}{4}\right)$. Li and Co atoms are alternately located on octahedral sites between adjacent close-packed (ccp) planes of oxygen. The unit cell of the LCO structures is presented in Figure 1. The ordered structure is known as HT-LiCoO due to its formation at a temperature higher than $600{ }^{\circ} \mathrm{C}$ (Figure 1a), while the low-temperature modification ( $\mathrm{LT}-\mathrm{LiCoO}_{2}$ ) is slightly disordered with a cubic structure (space group Fd3m; Figure 1b). The existence of the HT- $\mathrm{LiCoO}_{2}$ structure is generally confirmed by a distinct splitting of the (110)/(108) doublet of the XRD diffraction lines. Note in the ideal $c c p$ lattice the $c / a$ ratio is $2 \sqrt{ } 6$ (4.899). For the well-crystallized $\mathrm{HT}-\mathrm{LiCoO}_{2}$ phase synthesized by the sol-gel via malic acid assisted method, the c/a ratio is reported to be 4.987 [12]. Magnetic properties indicated that $\mathrm{LiCoO}_{2}$ consists of $\mathrm{Co}^{3+}\left(\mathrm{t}_{2 \mathrm{~g}}{ }^{6} \mathrm{eg}_{\mathrm{g}}{ }^{0}\right)$ ions in the low-spin state [13].

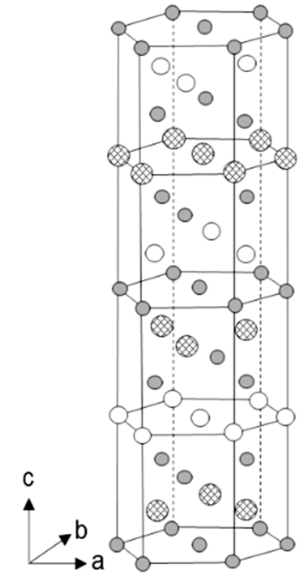

(a)

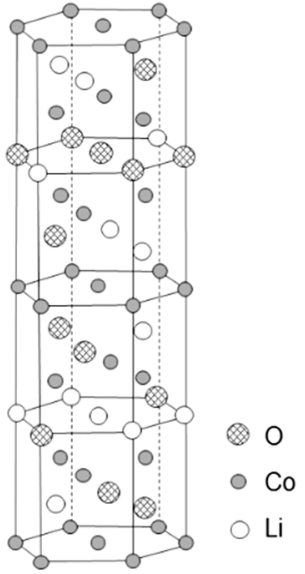

(b)

Figure 1. View of the structure of $\mathrm{LiCoO}_{2}$. (a) The high-temperature (HT) phase, rhombohedral structure (space group $R-3 m$ ). (b) The low-temperature (LT) phase, cubic structure (space group Fd3m). Reproduced with permission from [14]. Copyright 1995 Elsevier.

The investigation of electrochemical behavior of $\mathrm{Li}_{\mathrm{x}} \mathrm{CoO}_{2}$ by the cyclic voltammetry or galvanostatic method in both non-aqueous (aprotic) and aqueous electrolytes demonstrated the phase changes in the potential window 3.0-4.3 $\mathrm{V}$ due to the (de)intercalation reactions in the composition range $1.0 \geq x \geq 0.5[15,16]$. As shown in Figure 2, a typical voltammogram of $\mathrm{Li}_{\mathrm{x}} \mathrm{CoO}_{2}$ in organic electrolyte exhibits three anodic/cathodic couples. The broad peaks at $4.08 / 3.83 \mathrm{~V}$ are associated with the two-phase domain $(0.75 \geq x \geq 0.95)$ and the two pairs of redox peaks at $4.13 / 4.03$ and $4.21 / 4.14 \mathrm{~V}$ are related to the interlayer Li vacancy in-plane ordering [17]. $\mathrm{LiCoO}_{2}$ in a saturated $\mathrm{Li}_{2} \mathrm{SO}_{4}$ aqueous solution demonstrated similar electrochemical features [18].

Well-crystallized LCO films exhibit a clear discharge voltage plateau at ca. $4 \mathrm{~V} \mathrm{vs}$. $\mathrm{Li}^{+} / \mathrm{Li}$, but the discharge profile appears sloping for amorphous-like films. Most of the commercial all solid-state thin-film lithium microbatteries constructed with a $\mathrm{LCO}$ cathode, a fast $\mathrm{Li}^{+}$-ion conductor as the solid electrolyte, and a metallic $\mathrm{Li}$ anode, achieve initial specific capacities of $\sim 60 \mathrm{mAh} \mathrm{cm}^{-2} \mu \mathrm{m}^{-1}$ on 
discharge, which is close to the theoretical value $\sim 68.9 \mu \mathrm{Ah} \mathrm{cm}^{-2} \mu \mathrm{m}^{-1}$ or $248 \mathrm{mC} \mathrm{cm}^{-2} \mu \mathrm{m}^{-1}$ (i.e., corresponding to gravimetric capacity of $137 \mathrm{mAh} \mathrm{g}^{-1}$ for a density of $5.06 \mathrm{~g} \mathrm{~cm}^{-3}$ and Li uptake $x=0.5$ in $\left.\mathrm{Li}_{\mathrm{x}} \mathrm{CoO}_{2}\right)$ [19].
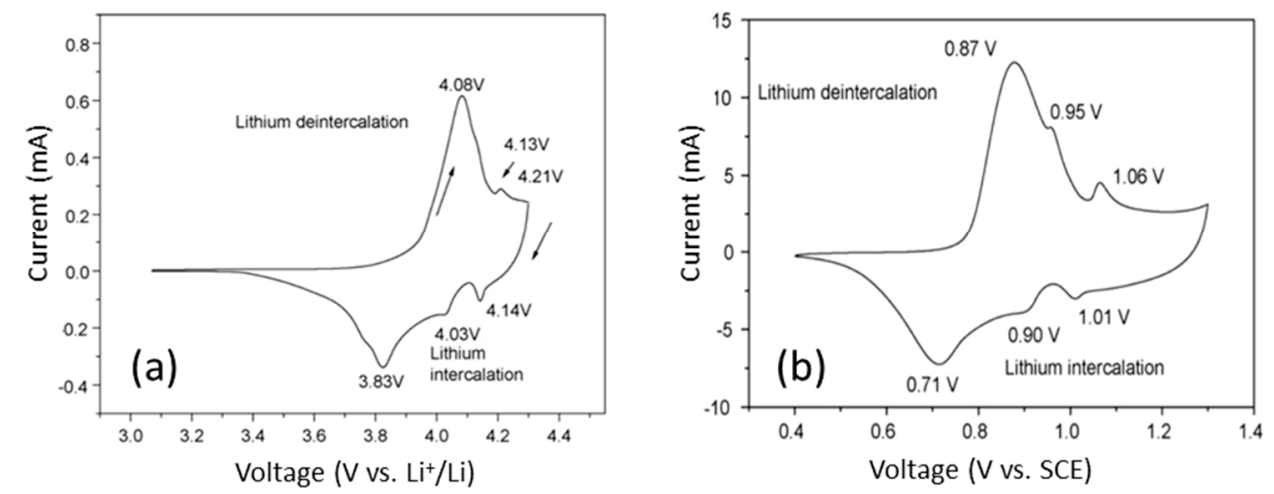

Figure 2. Cyclic voltammograms of $\mathrm{Li} / / \mathrm{LiCoO}_{2}$ obtained (a) in organic (aprotic) electrolyte at a scan rate of $0.1 \mathrm{mV} \mathrm{s}^{-1}$ and $(\mathbf{b})$ in saturated $\mathrm{Li}_{2} \mathrm{SO}_{4}$ aqueous electrolyte at scan rate of $0.6 \mathrm{mV} \mathrm{s}^{-1}$. Reproduced with permission from [18]. Copyright 2009 Elsevier.

Here, we report the structural and electrochemical properties of $\mathrm{LiCoO}_{2}$ thin films prepared by the rf-sputtering method, for which relationships are established between texture, experimental conditions, and performance as the cathode thin films. Applications of LCO films in lithium microbatteries are also examined. This paper is organized as follows: The all-solid-state lithium thin film batteries fabricated by the rf-sputtering technique are introduced in Section 2; the optimization of the growth of $\mathrm{LiCoO}_{2}$ thin films is presented in Section 3; a detailed examination of the influence of the sputtered conditions on the texture is given in Section 4 with an emphasis of the growth-parameter/microstructure relationship; the following thereof Section 5 reports the electrochemical properties (charge-discharge profiles and $\mathrm{Li}^{+}$ions kinetics) and a brief overview of the properties of doped $\mathrm{LiCoO}_{2}$ thin films.

\section{All Solid-State Lithium Microbatteries}

Today, the all-solid-state lithium batteries using solid electrolytes are considered to be the new generation of rechargeable batteries [20], but advances in this kind of power sources are constant since the 1990s. A typical all-solid-state microbattery (SSMB) is constituted by three main active materials sequentially deposited as thin layers on a substrate: $\mathrm{A} \sim 1-\mu \mathrm{m}$ thick metallic lithium as the negative electrode (anode), a $\sim 2-\mu \mathrm{m}$ thick solid-state inorganic electrolyte (SSE) as the separator, and a $\sim 2-3-\mu \mathrm{m}$ thick intercalation compound (IC) as the positive electrode (cathode). Alternative thin film anodes have been used such as $\mathrm{SiSn}_{0.87} \mathrm{O}_{1.20} \mathrm{~N}_{1.72}$ (SiTON), $\mathrm{Sn}_{3} \mathrm{~N}_{4}, \mathrm{Zn}_{3} \mathrm{~N}_{2}$, or $\mathrm{Cu}$ films [21]. The total thickness of SSMBs is of the order of $\sim 10-15 \mu \mathrm{m}$ including current collector and encapsulation (Figure 3). Table 1 lists the characteristics of all-solid-state lithium microbatteries with LCO cathode fabricated by the rf-sputtering technique.

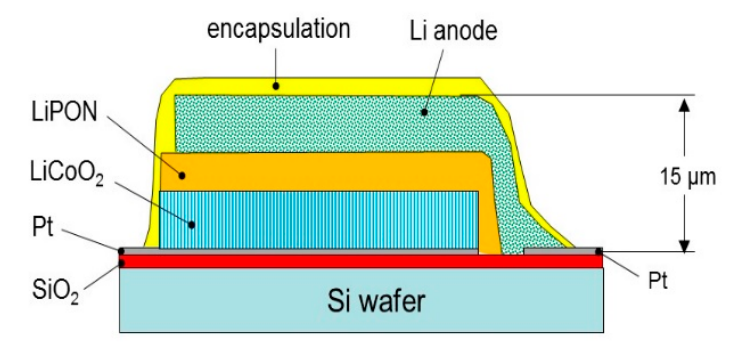

Figure 3. Schematic cross-section illustrating the layout of an all-solid-state thin-film battery. 
Table 1. All solid-state $\mathrm{Li}$ microbatteries with a $\mathrm{LiCoO}_{2}$ (LCO) cathode film fabricated by the RFsputtering technique.

\begin{tabular}{|c|c|c|c|}
\hline Electrochemical Chain & $\begin{array}{l}\text { Specific Capacity } \\
\left(\mu \mathrm{Ah} \mathrm{cm}^{-2} \mu \mathrm{m}^{-1}\right)\end{array}$ & $\begin{array}{c}\text { Cyclability @ Current } \\
\text { Density }\end{array}$ & Ref. \\
\hline $\mathrm{Li} / \mathrm{LiPON} / 6.2 \mu \mathrm{m} \mathrm{LCO} / \mathrm{Pt} / \mathrm{Ti} /$ glass & 40 & $40 @ 20 \mu \mathrm{A} \mathrm{cm} \mathrm{cm}^{-2}$ & [22] \\
\hline $\mathrm{Li} / 1.5 \mu \mathrm{m} \mathrm{LiPON} / \mathrm{Pt} / 3.7 \mu \mathrm{m} \mathrm{LCO}$ & 67 & $50 @ 200 \mu \mathrm{A} \mathrm{cm} \mathrm{cm}^{-2}$ & [23] \\
\hline $\mathrm{Li} / \mathrm{LiPON} / 0.5 \mu \mathrm{m} \mathrm{LCO} / \mathrm{Pt}$ & 50 & $140 @ 10 \mu \mathrm{A} \mathrm{cm}{ }^{-2}$ & [24] \\
\hline $\mathrm{Li} / 1.4 \mu \mathrm{m} \mathrm{LiPON} / 0.45 \mu \mathrm{m} \mathrm{LCO} / \mathrm{Au}$ & 40 & 800@0.4C $\left(10 \mu \mathrm{A} \mathrm{cm}^{-2}\right)$ & [25] \\
\hline $\mathrm{Li} / \mathrm{LiPON} / \mathrm{NASICON} / \mathrm{LCO} / \mathrm{Pt}$ & 15 & $50 @ 0.01 C$ & [26] \\
\hline $\mathrm{Li} / \mathrm{Li}_{2.64} \mathrm{PO}_{2.81} \mathrm{~N}_{0.33} / \mathrm{LCO} / \mathrm{Pt} / \mathrm{mica}$ & 22 & 800@10C & [27] \\
\hline $\mathrm{Li} / \mathrm{Li}_{3.09} \mathrm{BO}_{2.53} \mathrm{~N}_{0.52} / \mathrm{LCO} / \mathrm{Pt} / \mathrm{mica}$ & 44.3 & 1000@1C & [28] \\
\hline $\mathrm{Li} / \mathrm{LiPON} / \mathrm{LCO} / \mathrm{Au} / \mathrm{Ti} / \mathrm{SiO}_{2} / \mathrm{Si}$ & 58 & $30 @ 4 C$ & [29] \\
\hline $\mathrm{Li} / \mathrm{LiPON} / \mathrm{LCO} / \mathrm{Pt} / \mathrm{Ti} / \mathrm{TiO}_{2} / \mathrm{Al}_{2} \mathrm{O}_{3}$ & 60 & $500 @ 5 C$ & {$[30]$} \\
\hline
\end{tabular}

With respect to the requested low internal resistance, the challenges in a thin-film lithium cell arise from the low ionic conductivity of the SSE and the quality of the electrode-SSE interfaces. The most popular technique for the preparation of a cathode thin-film is radio-frequency magnetron sputtering (abbreviation RFS hereafter). The first SSMBs were developed using $\mathrm{TiS}_{2}, \mathrm{~V}_{2} \mathrm{O}_{5}$, and $\mathrm{LiMn}_{2} \mathrm{O}_{4}$ as ICs [2] and the fast-ion conductor lithium phosphorous oxynitride (LiPON) as a solid electrolyte. This material with a typical composition of $\mathrm{Li}_{3.3} \mathrm{PO}_{3.8} \mathrm{~N}_{0.22}$ exhibits an ionic conductivity of $2 \mu \mathrm{S} \mathrm{cm}{ }^{-1}$ at $25^{\circ} \mathrm{C}$, and it

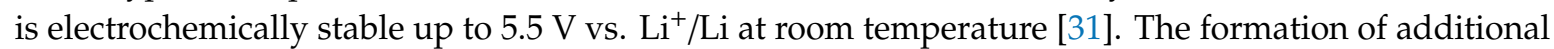
cross-linking between $\mathrm{PO}_{4}$ groups and the low electrostatic energy of $\mathrm{P}-\mathrm{N}$ bonds are the origin for high ionic conductivity [32]. Thin film of LiPON is easily fabricated by rf-magnetron sputtering of a $\mathrm{Li}_{3} \mathrm{PO}_{4}$ target in $\mathrm{N}_{2}$ atmosphere. Several groups have reported improved ionic transport for film with higher $\mathrm{N}$ content. Table 2 summarizes the $\mathrm{N} / \mathrm{P}$ ratio dependence of the electrical properties of LiPON films prepared by RF-sputtering.

Table 2. The ionic conductivity of LiPON films prepared by RF-sputtering.

\begin{tabular}{ccccc}
\hline Composition & Target & N/P Ratio & $\begin{array}{c}\text { Conductivity } \\
\left(\mathbf{S ~ c m} \mathbf{~}^{-1}\right)\end{array}$ & Ref. \\
\hline $\mathrm{Li}_{4.2} \mathrm{PO}_{2.8} \mathrm{~N}_{0.46}$ & $\mathrm{Li}_{3} \mathrm{PO}_{4}$ & 0.46 & $3.3 \times 10^{-6}$ & {$[33]$} \\
$\mathrm{Li}_{4.2} \mathrm{PO}_{2.8} \mathrm{~N}_{1.2}$ & $\mathrm{Li}_{3} \mathrm{PO}_{4}$ & 1.2 & $4.1 \times 10^{-7}$ & {$[34]$} \\
$\mathrm{Li}_{2.971} \mathrm{PO}_{1.875} \mathrm{~N}_{1.25}$ & $\mathrm{Li}_{3} \mathrm{PO}_{4}$ & 1.2 & $1.67 \times 10^{-6}$ & {$[35]$} \\
$\mathrm{Li}_{3.3} \mathrm{PO}_{2.1} \mathrm{~N}_{1.4}$ & $\mathrm{Li}_{3} \mathrm{PO}_{4}$ & 1.4 & $1.6 \times 10^{-6}$ & {$[36]$} \\
$\mathrm{Li}_{2.9} \mathrm{PO}_{2.9} \mathrm{~N}_{0.5}$ & $\mathrm{Li}_{3} \mathrm{PO}_{4}$ & 0.5 & $1.4 \times 10^{-6}$ & {$[37]$} \\
$\mathrm{Li}_{4.0} \mathrm{PO}_{3.9} \mathrm{~N}_{0.4}$ & $\mathrm{Li}_{3} \mathrm{PO}_{4}$ & 0.4 & $1.75 \times 10^{-6}$ & {$[38]$} \\
$\mathrm{Li}_{3.2} \mathrm{PO}_{3.0} \mathrm{~N}_{1.0}$ & $\mathrm{Li}_{3} \mathrm{PO}_{4}$ & 1.0 & $3.0 \times 10^{-6}$ & {$[38]$} \\
\hline
\end{tabular}

Since 1996, thin films of $\mathrm{LiCoO}_{2}$ emerged as promising cathode materials for SSMBs. Several techniques have been employed to grow $\mathrm{LiCoO}_{2}$ thin films: Radio-frequency magnetron sputtering (abbreviation rf-sputtering hereafter) [39], spray pyrolysis [40], pulsed-laser deposition (PLD) [41], physical vapor deposition (PVD) [42], etc. In the early work by Wang et al., $\mathrm{Li}_{1.15} \mathrm{CoO}_{2.16}$ (or $0.08 \mathrm{Li}_{2} \mathrm{O}$ enriched LCO) was prepared using a stoichiometric $\mathrm{LiCoO}$ target in an $\mathrm{Ar} / \mathrm{O}_{2}$ mixture gas with 3:1 ratio. For film annealed at $600-700{ }^{\circ} \mathrm{C}$, the discharge profiles exhibited the standard potential plateau $\sim 3.9 \mathrm{~V}$ with additional two lower capacity plateaus at $\sim 4.2$ and $\sim 4.1 \mathrm{~V}$. Over 104 cycles at current density of $100 \mu \mathrm{A} \mathrm{cm}^{-2}$, the capacity fading was $0.0001 \%$ and $0.002 \%$ for 50 - and $500-\mathrm{nm}$ thick thin film cathodes, respectively [39]. More recently, Song et al. [27] investigated the high-rate capability (up to $\left.10 \mathrm{C}\left(\sim 0.8 \mathrm{~mA} \mathrm{~cm}^{-2}\right)\right)$ of $\mathrm{Li} / \mathrm{Li}_{2.64} \mathrm{PO}_{2.81} \mathrm{~N}_{0.33} / \mathrm{LCO} / \mathrm{Pt}$ microcells $(2 \mathrm{~cm} \times 2 \mathrm{~cm} \times 10 \mu \mathrm{m})$ fabricated on a flexible substrates (mica) delivering an initial specific capacity of 39 and $22 \mu \mathrm{Ah} \mathrm{cm} \mathrm{cm}^{-2} \mathrm{~m}^{-1}$ at a $0.3 \mathrm{C}$ and $10 \mathrm{C}$ rate, respectively. The high rate and the excellent capacity retention of $95 \%$ over 800 cycles are promoted by the (104)/(101) planes of the LCO films. Recently, a bio-compatible 
flexible lithium-ion thin-film battery was powering the implantable orthodontic system [43,44]. The $\mathrm{Si} / \mathrm{SiO}_{2} / \mathrm{Al} / \mathrm{LCO}: \mathrm{LiPON} / \mathrm{Ti}$ microcell $(236 \mu \mathrm{g} ; 30 \mu \mathrm{m}$ total thickness) with an unprecedented volumetric energy of $200 \mathrm{mWh} \mathrm{cm}^{-3}$ worked over 120 cycles of continuous operation. The flexible SSMB based on the solid electrolyte of lithium boron oxynitride $\left(\mathrm{Li}_{3.09} \mathrm{BO}_{2.53} \mathrm{~N}_{0.52}(\mathrm{LiBON}), \sigma_{\mathrm{i}}=2.3 \mu \mathrm{S} \mathrm{cm}^{-1}\right)$ exhibits impressive high performance from $1 \mathrm{C}$ to $30 \mathrm{C}$ rate (Figure 4a) demonstrating an initial specific capacity of $49.2 \mu \mathrm{Ah} \mathrm{cm} \mathrm{cm}^{-2} \mu \mathrm{m}^{-1}$ at a $1 \mathrm{C}$ rate $\left(83.7 \mu \mathrm{A} \mathrm{cm}{ }^{-2}\right)$ with a capacity retention of $90 \%$ after 1000 cycles (Figure 4b) [28]. This microcell $\left(10-\mu \mathrm{m}\right.$ total thickness, $3 \mathrm{~cm}^{2}$ surface area) is a stack of a Pt thin layer deposited on a mica flexible substrate, a 1.7- $\mu \mathrm{m}$ thick LCO film deposited by a $\mathrm{rf} /$ direct-current hybrid magnetron sputtering technique in $1 \mathrm{~Pa}$ of Ar gas, a 1.5- $\mu \mathrm{m}$ thick LiBON film deposited from rf-sputtered $3 \mathrm{Li}_{2} \mathrm{O}-\mathrm{B}_{2} \mathrm{O}_{3}$ target under $0.4 \mathrm{~Pa}$ of $\mathrm{N}_{2}$ ambient and a 1- $\mu$ m thick lithium film deposited by thermal evaporation (Figure 4c). Recently, the $\mathrm{Li} / \mathrm{LiPON} / \mathrm{LCO} / \mathrm{Au} / \mathrm{Ti} / \mathrm{SiO}_{2} / \mathrm{Si}$ was fabricated using a solid electrolyte thin film deposited from Li-rich $\mathrm{Li}_{3} \mathrm{PO}_{4}$ target exhibiting an ionic conductivity of $3.2 \times 10^{-6} \mathrm{~S} \mathrm{~cm}^{-1}$ at $25^{\circ} \mathrm{C}$. This microcell delivered specific capacities of 64.5 and $58.0 \mu \mathrm{Ah} \mathrm{cm}^{-2} \mu \mathrm{m}^{-1}$ at a current rate of $0.1 \mathrm{C}$ and $4 \mathrm{C}$, respectively [29]. Another microcell with the $\mathrm{Li} / \mathrm{LiPON} / \mathrm{LCO} / \mathrm{Pt} / \mathrm{Ti} / \mathrm{TiO}_{2} / \mathrm{Al}_{2} \mathrm{O}_{3}$ configuration delivered impressive capacity of $60 \mu \mathrm{Ah} \mathrm{cm}^{-2} \mu \mathrm{m}^{-1}$ at a $5 \mathrm{C}$ rate without capacity fading after 500 cycles [30]. This superior cycling performance was attributed to the growth process that consisted in the deposition at $T_{\mathrm{S}}=600{ }^{\circ} \mathrm{C}$ without post-treatment. Such thin-film lithium microbatteries was developed as reserve batteries by GS Nanotech Co., Ltd. (Korea) [45].
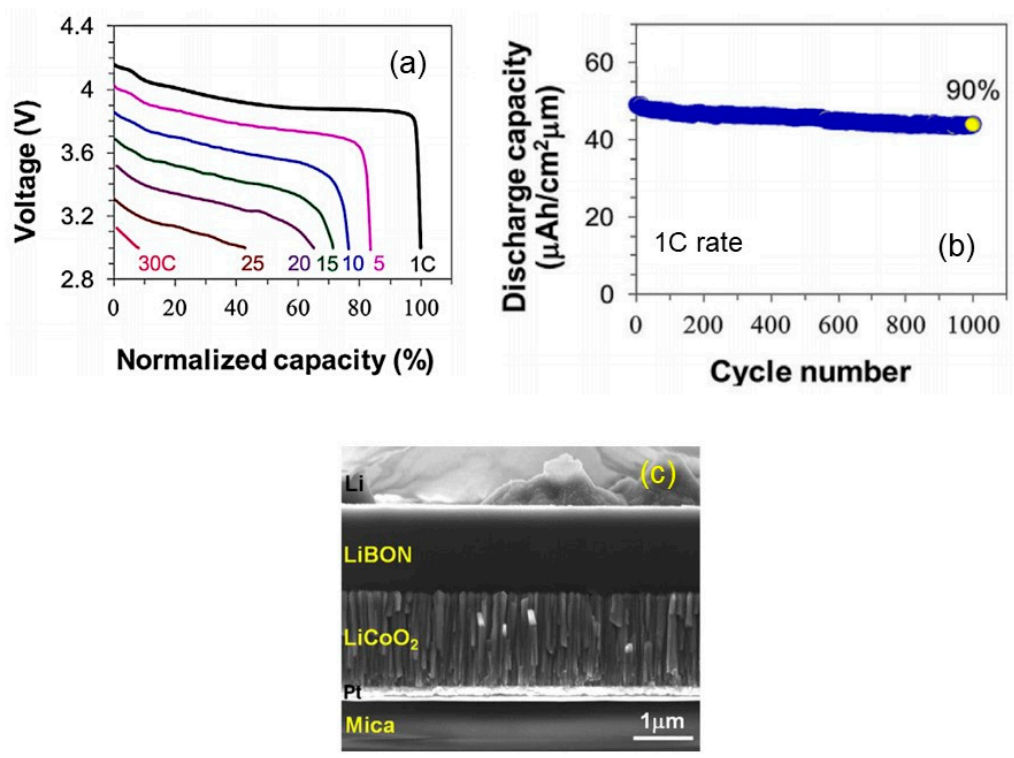

Figure 4. Flexible LiBON-based all-solid state microbattery, $\mathrm{Li} / \mathrm{LiBON} / \mathrm{LiCoO}_{2}$ (a) High-rate performance from $1 \mathrm{C}$ to $30 \mathrm{C}$. (b) Cyclability at $1 \mathrm{C}$ and $20^{\circ} \mathrm{C}$. (c) SEM cross-section image. Reproduced with permission from [28]. Copyright 2016 Elsevier.

\section{Growth of LCO Thin Films}

\subsection{RF-Magnetron Sputtering}

In this Section, we discussed the influence of the sputtering conditions on the preferential orientations of LCO films, which are generally related to the minimization of the energy during crystal growth. Composition of the $\mathrm{Ar} / \mathrm{O}_{2}$ gas mixture, gas flow rate, pressure, nature of the substrate, substrate temperature $\left(T_{\mathrm{s}}\right)$, deposition rate $\left(\Theta_{\mathrm{dr}}\right)$, and annealing temperature $\left(T_{\mathrm{a}}\right)$ were considered. LCO material being highly anisotropic (lamellar structure), the thin-film deposition process must produce desirable crystalline texture that favors the lithium diffusion at the electrode-electrolyte interface. Typically, there are three structural configurations: (003), (101), and (104) as shown in Figure 5. Due to the 
layered structure of LCO, the main issue for high electrochemical performance is the orientation of grains. Grain orientation in the (003) direction does not lead to high discharge capacity, in this case $\mathrm{Li}^{+}$ions passed through the grain boundaries. In contrast, (104)- and (101)-oriented grains favor the $\mathrm{Li}^{+}$-ion transport. It has been shown that the mechanism responsible for the $\mathrm{LCO}$ thin film texture is the volumetric strain energy imposed by thermal mismatch between the film and the substrate during the annealing process [46]. Thus, orientations of grains are dependent of several factors such as the surface state of the substrate and sputter deposition conditions.

The use of an argon atmosphere only results in sputtered films with (003) and (102) planes parallel to the substrate due to the absence of oxygen recombination at the surface. In contrast, the use of a mixture of $\mathrm{Ar} / \mathrm{O}_{2}$ gas results in dense film and preferred (101) or (104) orientation after subsequent heat treatment. For such films, the structure has an open channel at the interface with the solid electrolyte, which facilitates the Li diffusion from the film surface and lowers the transfer resistance. On the other hand, the growth of LCO films under mixed-gas atmosphere requires less stringent annealing process, i.e., lower annealing temperature of $\sim 300^{\circ} \mathrm{C}$. Trask et al. [47] demonstrated that crystallographic texture of LCO films thicker than $5 \mu \mathrm{m}$ deposited with an oxygen concentration of $4 \%$ in $\mathrm{Ar}$, with a total flow rate controlled to $50 \mathrm{sccm}$ and an operating pressure of $0.5 \mathrm{~Pa}$, shows no detectable (003) peak after annealing at $800^{\circ} \mathrm{C}$ for $1 \mathrm{~h}$. Using such conditions, all solid-state microcells (Figure 3) fabricated with a $\sim 15-\mu \mathrm{m}$ thick cathodes exhibited discharge capacities of $60 \mu \mathrm{Ah} \mathrm{cm}^{-2} \mu \mathrm{m}^{-1}\left(600 \mu \mathrm{Ah} \mathrm{cm}^{-2}\right.$ as per cathode) at C/10 rate and a capacity retention greater than $95 \%$ after 100 cycles at a $C / 5$ discharge rate. Yoon et al. [48] made $\mathrm{LCO}$ thin film electrodes on $\mathrm{Li}_{2} \mathrm{O} / \mathrm{Al} / \mathrm{Si}$ substrates. The use of $\mathrm{Li}_{2} \mathrm{O}$ acts as buffer that suppresses the formation of the Li-deficient phase and avoids the lattice mismatch between $\mathrm{LCO}$ and $\mathrm{Al}$ (111) plane that was responsible for the growth of (003) plane. By increasing the substrate temperature, the difference in surface energy between the orientations of the atomic planes of $\mathrm{LiCoO}_{2}$ is reduced. As a result, the (003)-preferred orientation turns to the (101) one, as observed for 400-nm thick $\mathrm{LiCoO}_{2}$ films. This illustrates the strong dependence of the texture on the growth conditions.

Films of lithium cobalt oxide were firstly demonstrated by Wei et al. in 1992 [49], who applied the rf-sputtering method using a crystalline $\mathrm{LiCoO}_{2}$ target for smart window application. As-prepared LCO films were nanocrystalline with some (003) out-of-plane texturing due to the substrate temperature held at $300{ }^{\circ} \mathrm{C}$. Films were deposited on various substrates, i.e., tin-indium-oxide coated glass, single crystal of $\mathrm{NaCl}$, and $\mathrm{Ni}$-coated glass, using the following experimental parameters: The target positioned $8 \mathrm{~cm}$ below the substrate holder, the sputtering $\mathrm{Ar} / \mathrm{O}_{2}$ gas mixture of $6: 14$, $\mathrm{rf}$ power of $100 \mathrm{~W}, \mathrm{~T}_{\mathrm{s}}=300{ }^{\circ} \mathrm{C}$, and $\Theta_{\mathrm{dr}}=0.83 \mathrm{~nm} \mathrm{~min}{ }^{-1}$. Under these conditions, the 200-nm thick films were $\mathrm{Li}$ deficient $\left(\mathrm{Li}_{\mathrm{x}} \mathrm{CoO}_{2-\mathrm{y}}\right.$ with $x=0.4$ and $y=0.08$; Co oxidation state of 3.46) and retained the basic layered $\alpha-\mathrm{NaFeO}_{2}$-like structure showing a strong (003) orientation. Since this prior work, substantial efforts have been made over the past decade to prepare LCO thin films by sputtering techniques with well-defined texture and orientation favorable for high electrochemical performance.

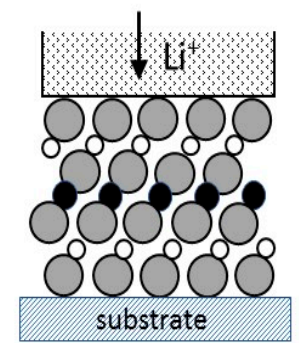

(003)

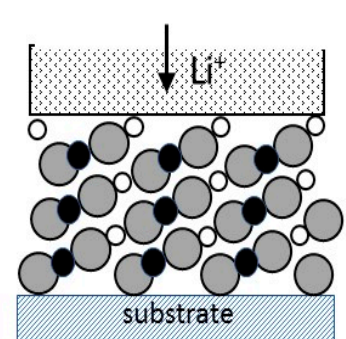

(101)

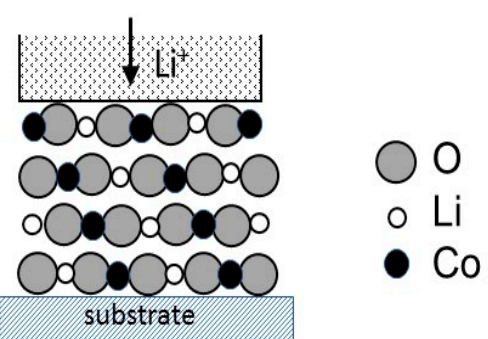

(104)

Figure 5. Schematic diagram showing the preferred textures for sputtered LCO films. The close-packed (ccp) (003) plane does not allow easy intercalation at the electrolyte-electrode interface, while (101) and (104) textures favor the easy diffusion path of $\mathrm{Li}^{+}$ions in LCO grains of LCO films. 
The influence of the cathode thickness on the electrochemical properties of SSMBs has been investigated in the range extending from $50 \mathrm{~nm}$ to $4 \mu \mathrm{m}$ [50]. The LCO films were prepared by rf-sputtering in an Ar plasma of 2.7 Pa at the deposition rate of 4-10 $\mathrm{nm} \mathrm{min}{ }^{-1}$. Oxygen-rich as deposited films (amorphous texture) were subsequently annealed at $700{ }^{\circ} \mathrm{C}$ for $2 \mathrm{~h}$ for reducing the $\mathrm{O} / \mathrm{Co}$ ratio. Microcells using a 3- $\mu \mathrm{m}$ thick LiPON film as SSE cycled in the voltage range 3.0-4.2 V showed that shapes of the discharge profiles depend on the cathode thickness $\delta$. For $\delta=50 \mathrm{~nm}$, the lithium equilibration is very fast in the cathode and the discharge capacity of $\sim 1.8 \mu \mathrm{Ah} \mathrm{cm}^{-2}$ is almost independent of the current density in the range 2-500 $\mu \mathrm{A} \mathrm{cm}^{-2}$. For $\delta=54 \mu \mathrm{m}$, the Li transport becomes very slow in the thick cathode and the specific capacity decreased from 290 to $200 \mu \mathrm{Ah} \mathrm{cm}{ }^{-2}$ with the increase of the current density from 20 to $1000 \mu \mathrm{A} \mathrm{cm}^{-2}$, respectively. Despite the lack of texture analysis, it seems that $70 \%$ of the maximum capacity for thicker film is due to the non-favorable orientation of the grains in LCO films. Whitacre et al. [51] examined the influence of target aging and deposition geometry on sputtered LCO thin films prepared with target power of $100 \mathrm{~W}$ (power density of $2.2 \mathrm{~W} \mathrm{~cm}^{-2}$ ) under $\mathrm{Ar} / \mathrm{O}_{2}$ mixed gas ( $\mathrm{Ar}$ to $\mathrm{O}_{2}$ ratio 3:1) with a total gas flow rate of $55 \mathrm{sccm}$ and pressure of $1 \mathrm{~Pa}$. Results showed that these films sputtered from an heavily used target were Li-deficient, while the use of fresh target produced Li-rich LCO films. A 200-nm thick LCO films deposited on a Si substrate at $T_{\mathrm{S}}=25{ }^{\circ} \mathrm{C}$ from a fresh pre-sputtered target exhibited a strong degree of (104) out-of-plane texture. As a result, caution must be taken to pre-activate the LCO target by pre-sputtering for at least $30 \mathrm{~min}$. In a recent application, Huang et al. [52] patented a sequential method for improving the LCO thin film cathodes that are multilayer films with alternating process conditions. First, sputtering deposition of an LCO layer in $\mathrm{Ar} / \mathrm{O}_{2}$ gas mixture; second, annealing at a predetermined temperature, at least $300^{\circ} \mathrm{C}$; third, deposition of another very thin LCO film on the annealed one in pure Ar atmosphere, which strengthens the first layer; fourth, depositing a third LCO layer using an $\mathrm{Ar} / \mathrm{O}_{2}$ mixture. Yoon et al. used a two-step heat treatment to prepare crack-free LCO films using the rapid thermal annealing (RTA) method [30]. It is notable that the (003)-, (104)-, and (018)-plane textures vanish with the increase of $T_{\mathrm{s}}$, while the (101) plane is not affected. XRD patterns showed that the volume strain energy of the (101) and (104) planes is minimized for thick films $(\delta \geq 1 \mu \mathrm{m})$, which is due to differential thermal expansion between the film and the substrate [53]. The polycrystalline LCO films deposited on the $\mathrm{Au} / \mathrm{Ti} / \mathrm{SiO}_{2} / \mathrm{Si}$ substrate from the Li-rich $\mathrm{Li}_{1.1} \mathrm{CoO}_{2}$ target and annealed at a moderate temperature of $650{ }^{\circ} \mathrm{C}$ showed preferential (101) and (104) plane orientation [54]. Electrochemical tests in the range of 3.0-4.2 V at a current density of $50 \mu \mathrm{A} \mathrm{cm}{ }^{-2}$ displayed a capacity of $58 \mu \mathrm{Ah} \mathrm{cm}^{-2} \mu \mathrm{m}^{-1}$ at the 20th cycle with a small capacity fade. LCO films sputtered in $40 \mathrm{sccm}$ argon flow (pressure of $0.2 \mathrm{~Pa}$ ) on $\mathrm{Si} / \mathrm{SiO}_{2} / \mathrm{Ti}$ stack and annealed at $650{ }^{\circ} \mathrm{C}$ for $2 \mathrm{~h}$ in vacuum exhibited a (104) preferred orientation and the lowest electrical resistivity of $0.37 \Omega \mathrm{cm}$ [55].

\subsection{Electron Cyclotron Resonance (ECR) Sputtering}

The Nippon Telegraph and Telephone's group (Japan) [22,56] used the electron cyclotron resonance (ECR) plasma sputtering method to grow LCO films as cathodes in SSMBs. The authors claimed that this technique, which employs high-energy ionic radiation, could produce well-crystallized $\mathrm{LiCoO}_{2}$ films without a post-heating treatment by adopting favorable deposition conditions. ECR plasma, which includes $\mathrm{Ar}$ and $\mathrm{O}_{2}$ gas flow is generated by introducing microwaves ( $2.45 \mathrm{Ghz}$ ) into a magnetic field. In the first investigation, the $\mathrm{LCO}$ films were prepared from sputtered $\mathrm{Li}_{\mathrm{x}} \mathrm{CoO}_{2}$ targets with Li-enriched composition in the range $1.0 \leq x \leq 2.0$. The sputtering process (microwave and rf powers of 800 and $500 \mathrm{~W}$, respectively) was carried out at $T_{\mathrm{s}}=300{ }^{\circ} \mathrm{C}$ under fixed $\mathrm{Ar} / \mathrm{O}_{2}$ gas ratio of $40: 1$ with a total pressure of $0.14 \mathrm{~Pa}$. The 3.7- $\mu \mathrm{m}$ thick cathode films deposited on a 500-nm thick Pt layer showed a pure HT- $\mathrm{LiCoO}_{2}$ phase when obtained for the Li-rich target $(x=2)$. Such a thin film electrode exhibited good electrochemical properties, i.e., $68 \mu \mathrm{Ah} \mathrm{cm}^{-2} \mu \mathrm{m}^{-1}$ at $0.2 \mathrm{~mA} \mathrm{~cm}{ }^{-2}$ discharge current. The $6.2 \mu \mathrm{m}$ thick films similarly produced were utilized in $\mathrm{Li} / \mathrm{LiPON} / \mathrm{LCO} / \mathrm{Pt} / \mathrm{Ti} /$ quartz glass SSMBs that provided a discharge capacity of about $250 \mu \mathrm{Ah} \mathrm{cm}^{-2}\left(40.3 \mu \mathrm{Ah} \mathrm{cm}^{-2} \mu \mathrm{m}^{-1}\right)$ with good cycle ability [22]. This 
low specific capacity was attributed to the presence of $\mathrm{Co}_{3} \mathrm{O}_{4}$ impurities and the (003) out-of-plane texture, due to the absence of post-treatment.

\section{Influence of Preparation Conditions}

A good knowledge of the relationship between the process parameters and the resultant structure of the film is required to obtain the desired properties of the deposit [57-70]. The monitoring of many rf-sputtering parameters, i.e., sputter power, working atmosphere, working pressure, target-substrate distance $\left(d_{s t}\right)$, and deposition temperature $\left(T_{\mathrm{s}}\right)$, allows us to control the texture, orientation and crystallinity of LCO thin films. RF sputtering improved the density and homogeneity of thin films that favor the low thin-film resistance. Currently, SSMBs are fabricated on a rigid substrate, i.e., silicon, alumina, or on a flexible substrate, i.e., mica. A polyimide (pyromellitimide-1,4-diphenyl ether made by Dupont under the trade-name Kapton) was also used as a cell supporting substrate [57]. LCO cathode thin films are deposited on a thin noble metal, i.e., Pt [58], Au [69], Ag [60], Cu foil [61], or Al layer [62], which acts as the current collector; both films are deposited on the top of a $\mathrm{SiO}_{2}$ layer, which electronically insulates the electrode from the silicon wafer. Sometimes, an additional Ti layer (30-nm thick) is deposited to enhance the adhesion of $\mathrm{Pt}$ to the $\mathrm{SiO}_{2}$ surface. Table 3 lists the various experimental conditions taken from the literature for the preparation of LCO thin films deposited by rf-sputtering technique along with the main electrochemical performance. According the literature, typical RF sputtering deposition of LCO thin films is realized under the following experimental conditions: The radio frequency is $13.56 \mathrm{MHz}$, the target-substrate distance is $d_{s t}=50-80 \mathrm{~mm}$, and the sputtering power density varies from 1.2 to $5.0 \mathrm{~W} \mathrm{~cm}^{-2}$. 
Table 3. Experimental conditions for the preparation of LCO thin films deposited by the rf-sputtering technique.

\begin{tabular}{|c|c|c|c|c|c|c|}
\hline Atmosphere ${ }^{\text {a) }}$ & $\begin{array}{l}\text { Power } \\
\text { (W) }\end{array}$ & $\begin{array}{c}\text { Deposition } \\
\text { Rate } \\
\left(\mathrm{nm} \mathrm{s}^{-1}\right)\end{array}$ & Substrate & $\begin{array}{c}\text { Substrate } \\
\text { Temperature } \\
\left({ }^{\circ} \mathrm{C}\right)\end{array}$ & Structural/Electrochemical Properties ${ }^{\text {c) }}$ & Ref. \\
\hline 3:1/55/1.0 & 100 & 3.2 & Si (100) wafer & 25 & Influence of the target history and deposition geometry & [51] \\
\hline $9: 3 / 12 / 5$ & 100 & & $\mathrm{Si} / \mathrm{SiO}_{2} / \mathrm{Ti} / \mathrm{Pt}$ & 250 & $T_{\mathrm{a}}=700^{\circ} \mathrm{C}, Q_{\mathrm{d}}=61 \mu \mathrm{Ah} \mathrm{cm}^{-2} \mu \mathrm{m}^{-1} ; R_{\mathrm{c}}=74 \%$ after 50 cycles & [63] \\
\hline $3: 1 / 40 / 0.5$ & 80 & 1.6 & $\mathrm{Si} / \mathrm{Ti} / \mathrm{MgO} / \mathrm{Pt}$ & 10 & 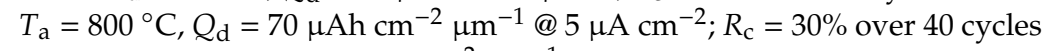 & [64] \\
\hline $96: 4 / 50 / 0.5$ & $2.75^{b)}$ & $\sim 0.3$ & $\mathrm{Al}_{2} \mathrm{O}_{3} / \mathrm{Ti} / \mathrm{Au}$ & $\sim 110$ & $T_{\mathrm{a}}=800{ }^{\circ} \mathrm{C}, Q_{\mathrm{d}}=60 \mu \mathrm{Ah} \mathrm{cm}^{-2} \mu \mathrm{m}^{-1} @ \mathrm{C} / 10 ; R_{\mathrm{c}}=95 \%$ over 100 cycles & [47] \\
\hline $9: 1 /-/ 0.5$ & $4.4^{\mathrm{b})}$ & & $\mathrm{Si} / \mathrm{Pt}$ and $\mathrm{Cu}$ foil & 200 & $T_{\mathrm{a}}=700^{\circ} \mathrm{C}, Q_{\mathrm{d}}=52 \mu \mathrm{Ah} \mathrm{cm}^{-2} \mu \mathrm{m}^{-1} @ 50 \mu \mathrm{A}$ & [61] \\
\hline $5: 1 / 150 / 0.2$ & 130 & 0.03 & Al foil & 65 & $c, Q_{\mathrm{d}}=46 \mu \mathrm{Ah} \mathrm{cm}-2 \mu \mathrm{m}^{-1} @ 5 \mu \mathrm{A} \mathrm{cm}-2 ; R_{\mathrm{c}}=78 \%$ over 100 cycles & [65] \\
\hline $9: 1 /-/ 0.5$ & 150 & 0.1 & $\mathrm{Si} / \mathrm{Al} / \mathrm{Li}_{2} \mathrm{O}$ & 25 & (101)-oriented; $Q_{\mathrm{d}}=40 \mu \mathrm{Ah} \mathrm{cm}{ }^{-2} \mu \mathrm{m}^{-1} @ 20 \mu \mathrm{A} \mathrm{cm}-2 ; R_{\mathrm{c}}=78 \% @ 640 \mu \mathrm{Acm}^{-2}$ & [48] \\
\hline $4: 1 / 150 / 0.27$ & 130 & 0.05 & Stainless steel & 25 & $Q_{\mathrm{d}}=44 \mu \mathrm{Ah} \mathrm{cm}{ }^{-2} \mu \mathrm{m}^{-1} @ 10 \mu \mathrm{A} \mathrm{cm}^{-2} ; R_{\mathrm{c}}=66 \%$ after 30 cycles & [66] \\
\hline $3: 1 / 53 / 2.2$ & 500 & & Al foil & 25 & $T_{\mathrm{a}}=500{ }^{\circ} \mathrm{C}, Q_{\mathrm{d}}=50 \mu \mathrm{Ah} \mathrm{cm}-2 \mu \mathrm{m}^{-1} @ 10 \mu \mathrm{A} \mathrm{cm}^{-2} ; R_{\mathrm{c}}=80 \%$ after 800 cycles & [25] \\
\hline $1: 0 /-/ 2.0$ & 100 & 8.3 & $\mathrm{Au}$ & 25 & Kinetics of (104)-plane. $D_{\mathrm{Li}} \approx 10^{-10}-10^{-12} \mathrm{~cm}^{2} \mathrm{~s}^{-1}$ & [67] \\
\hline $2: 1 /-/ 0.5$ & 200 & & Pt wafer & 55 & Power of $200 \mathrm{~W}, Q_{\mathrm{d}}=61 \mu \mathrm{Ah} \mathrm{cm} \mathrm{cm}^{-2} \mu \mathrm{m}^{-1} @ 20 \mu \mathrm{A} \mathrm{cm} \mathrm{cm}^{-2}$ & [68] \\
\hline $40: 1 / 20 / 0.14$ & 500 & 1 & Quartz/Pt & 300 & 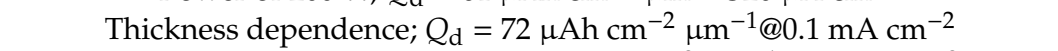 & [23] \\
\hline $3: 1 / 12 / 2$ & 100 & & $\mathrm{Si} / \mathrm{Pt}$ & $25-600$ & $T_{\mathrm{s}}=250{ }^{\circ} \mathrm{C}, T_{\mathrm{a}}=600^{\circ} \mathrm{C}, Q_{\mathrm{d}}=50 \mu \mathrm{Ah} \mathrm{cm}^{-2} \mu \mathrm{m}^{-1} @ 10 \mu \mathrm{A} \mathrm{cm}-2$ & [70] \\
\hline $9: 1 /-/ 0.5$ & 50 & 0.8 & Sapphire/SiO $2 / \mathrm{Al}$ & 25 & $T_{\mathrm{a}}=500{ }^{\circ} \mathrm{C}$, thermal conductivity $3.7 \mathrm{~W} \mathrm{~m}^{-1} \mathrm{~K}^{-1}$ for $\mathrm{Li}_{0.6} \mathrm{CoO}_{2}$ & [71] \\
\hline $9: 3 / 12 / 0.5$ & 50 & 0.02 & $\mathrm{Si} / \mathrm{SiO}_{2} / \mathrm{Pt}$ & 25 & $T_{\mathrm{a}}=800^{\circ} \mathrm{C}, Q_{\mathrm{d}}=27 \mu \mathrm{Ah} \mathrm{cm}{ }^{-2} \mu \mathrm{m}^{-1} @ 50 \mu \mathrm{A} \mathrm{cm}{ }^{-2}$ after 150 cycles & [72] \\
\hline
\end{tabular}

a) Composition of the Ar: $\mathrm{O}_{2}$ gas mixture/flow rate in standard cubic centimeter per minute (sccm)/chamber pressure in Pa; b) Specific sputtering power in $\mathrm{W} \mathrm{cm}^{-2}$; c) $T_{\mathrm{a}}=\mathrm{optimum}$ annealing temperature; $Q_{\mathrm{d}}=$ specific discharge capacity; $R_{\mathrm{c}}$ capacity retention. 
However, some precautions must be taken. For obtaining good quality LCO thin films with adequate surface chemical composition and morphology that dictate their electrochemical performance, it is necessary to pre-sputter the virgin target for at least 2 to $3 \mathrm{~h}$ at high rf-power to eliminate the surface contamination. To avoid lithium deficient LCO film due to sputtering over a prolonged period [51], Kusuril proposed the use of a powder target rather than a solid one, i.e., pressed and sintered pellet of ceramic powder and binder material [61]. The deposition rate is also an important parameter for the growth a stoichiometric LCO thin films. This factor was first established by Bates et al. [46] reporting the mechanism for the preferential orientation of LCO grains grown on a (100)Si/Co/Pt substrate. By combining the deposition rates in the range $1-10 \mathrm{~nm} \mathrm{~min}^{-1}$ and the deposition temperature in the range $50-300{ }^{\circ} \mathrm{C}$, different degrees of (003), (101), and (104) orientations were determined. It was also mentioned that at high substrate temperature, due to the increase of the surface mobility of adatoms, the texture changed from (101)-(104) to (003). As shown in Table 3, one observes a wide range of $\Theta_{\mathrm{dr}}$ values using by the researchers. Nevertheless, it appeared that $\Theta_{\mathrm{dr}}$ varies with both the working pressure (Figure 6a) and the concentration of oxygen in the $\mathrm{Ar} / \mathrm{O}_{2}$ gas mixture (Figure $6 \mathrm{~b}$ ).
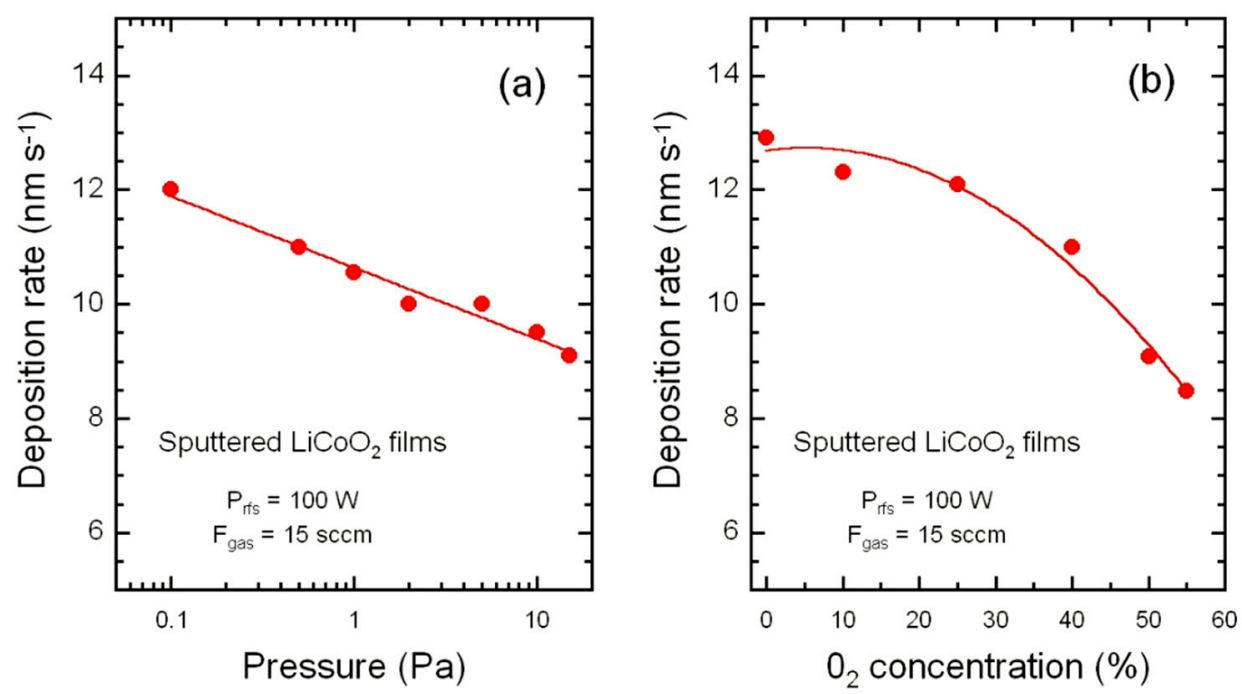

Figure 6. Evolution of the sputtering deposition rate of LCO films as a function of the working pressure (a) and the $\mathrm{O}_{2}$ concentration in the $\mathrm{Ar} / \mathrm{O}_{2}$ gas mixture (b).

\subsection{Influence of the Substrate}

$\mathrm{LiCoO}_{2}$ thin films have been prepared on varieties of substrates (see Table 2), the most popular being (100)-oriented silicon. However, to avoid the reaction of Si with LCO (because Si forms an alloy with $\mathrm{Li}$ ), a thin layer of $\mathrm{SiO}_{2}$ and a metallization is formed (see Figure 3). Lee et al. [72] studied the influence of the substrate, i.e., sintered alumina and $\mathrm{SiO}_{2} / \mathrm{Si}(100)$ substrates, on the microstructure of sputtered LCO thin films. Film were deposited at the rate of $0.9-1.2 \mathrm{~nm} \mathrm{~min}^{-1}$ in the presence of $0.5 \mathrm{~Pa}$ $\mathrm{Ar} / \mathrm{O}_{2}$ mixture gas (9:3 ratio) flowing at $12 \mathrm{sccm}$ and post-annealed at $800{ }^{\circ} \mathrm{C}$ in $\mathrm{O}_{2}$ atmosphere for $30 \mathrm{~min}$. For both substrates, a $300 \mathrm{~nm}$-thick layer of $\mathrm{Pt}$ was deposited as the current collector.

$\mathrm{LCO}$ films deposited on $\mathrm{Al}_{2} \mathrm{O}_{3} / \mathrm{Pt}$ substrates displayed a rough surface with several cracks induced by thermal expansion of the substrate, while films deposited on $\mathrm{Si} / \mathrm{SiO}_{2} / \mathrm{Ti} / \mathrm{Pt}$ substrates consisted of small grains without cracks. Such films exhibited the specific capacity of $27 \mu \mathrm{Ah} \mathrm{cm}{ }^{-2} \mu \mathrm{m}^{-1}$ at a current density of $50 \mu \mathrm{A} \mathrm{cm}^{-1}$ after 150 cycles with an average capacity decrease rate of $0.05 \%$ per cycle. Jeevan-Kumar et al. [73] produced LCO thin films (1.8 $\mu \mathrm{m}$ thick) from a Li-enriched $(10 \%)$ sintered 3-in $\mathrm{LiCoO}_{2}$ target to compensate the volatility of $\mathrm{Li}$. These films deposited on metallized Si substrate kept at $T_{\mathrm{s}}=250{ }^{\circ} \mathrm{C}$ with subsequent annealing at $650{ }^{\circ} \mathrm{C}$ under an oxygen pressure of $5 \mathrm{~Pa}$ showed a well-oriented $\mathrm{HT}-\mathrm{LiCoO}_{2}$ phase with predominant (104) planes. The high c/a ratio of 4.997 characterized the layered $(R-3 m)$ structure. Jeong et al. [74] interposed a thin $\mathrm{Al}_{2} \mathrm{O}_{3}$ layer 
(10 $\mathrm{nm}$ thick) deposited at the rate of $3.5 \mathrm{~nm} \mathrm{~min}^{-1}$ between the LCO film cathode and the LiPON film electrolyte, which decreases the interfacial resistance owing to the formation of a solid solution $\mathrm{LiCo}_{1-y} \mathrm{Al}_{\mathrm{y}} \mathrm{O}_{2}$ at the interface during the heat treatment at $400{ }^{\circ} \mathrm{C}$ for $5 \mathrm{~h}$. The same group identified the importance of substrate texturing and the formation of $\mathrm{LCO}$ film avoiding post-deposition treatment. The morphology of the LCO thin-film deposited on the $\mathrm{Au} / \mathrm{Ti} / \mathrm{SiO}_{2}$ stack was investigated as a function of the substrate texture using polished $\mathrm{Si}$ and textured $\mathrm{Si}$ (obtained by chemical etching using the $\mathrm{H}_{2} \mathrm{O}: \mathrm{HCl}: \mathrm{H}_{2} \mathrm{O}_{2}$ (6:1:1) solution; Figure 7). Surprisingly, the films deposited on textured Si having (003)-oriented grains (as per XRD patterns) delivered better capacity retention than the (104)-oriented films grown on polished-Si substrate. However, the film deposited on polished $\mathrm{Si}$ and heat-treated at $650{ }^{\circ} \mathrm{C}$ displayed the high initial discharge capacity of $60 \mu \mathrm{Ah} \mathrm{cm}^{-2} \mu \mathrm{m}^{-1}$ [75]. Taking the advantage of the direct deposition on a metal substrate acting as the current collector, similar behavior was obtained on stainless-steel (STS304) foil. Despite its cost, the Au current collector film can favor the preferred orientation of the $\mathrm{LiCoO}_{2}$ thin film cathode. A comparison between textured and annealed STS304 was established [66]. Using an $\mathrm{Ar} / \mathrm{O}_{2}$ mix gas of (4:1), the substrate having a strong (220) texture produces LCO films with a (003) preferred orientation, while the film deposited on annealed STS304 exhibited the (104) preferred orientation. As a result, the initial discharge capacity of the film deposited on the annealed stainless steel was higher than that of the film deposited on the textured substrate, but reverse behavior was observed for the LCO cathode cyclability. When Al foil is used as substrate, the degree of crystallization of the sputtered LCO films varies with the thickness of the $\mathrm{Al}$ coating deposited on the $\mathrm{Al}$ foil. The thinner the $\mathrm{Al}$ coating, the faster the crystallization process [63].

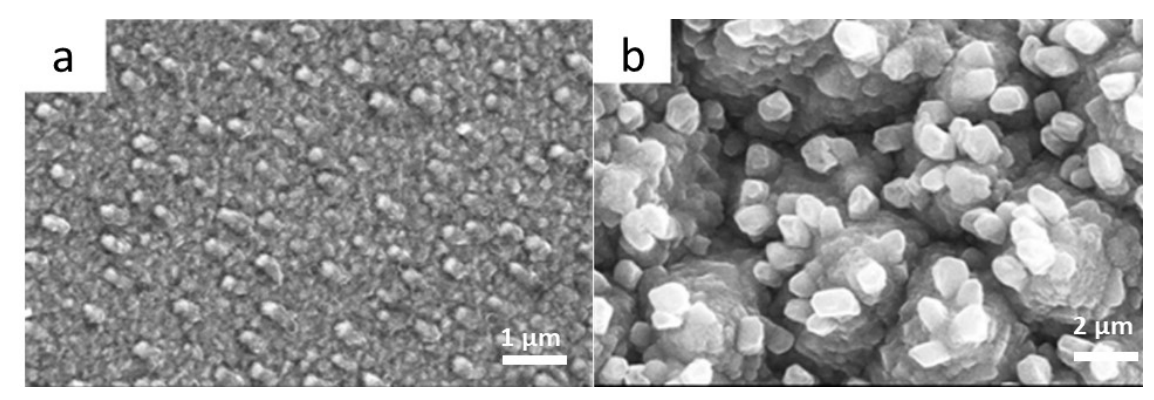

Figure 7. SEM images of as-sputtered LCO thin films deposited (a) on polished Si substrate and (b) on textured Si substrate obtained by chemical etching. The film (b) consists of layered like grains mostly distributed as individual clusters composed of few numbers of rough grains, which were vertically agglomerated. Reproduced with permission from [75]. Copyright 2014 Elsevier.

\subsection{Deposition Conditions}

In this section, we examined the relationship between the structure and morphology of LCO films and the experiments conditions, i.e., substrate temperature, deposition rate, sputter power, working pressure, substrate bias, and post-annealing process. The use of a heated substrate rather than a deposition at room temperature has been a debating issue. In most cases, the films deposited at $T_{\mathrm{S}}=25^{\circ} \mathrm{C}$ were found to be amorphous and subsequently developed a (003), (101), (110), or (104) out-of-plane texture upon annealing, depending on thickness [39,49]. Stockhoff et al. [14] stated that a lattice structure similar to the $\mathrm{LT}-\mathrm{LiCoO}_{2}$ phase is obtained at $T_{\mathrm{S}}<300^{\circ} \mathrm{C}$, while $\mathrm{HT}-\mathrm{LiCoO}_{2}$ is prepared at $T_{\mathrm{s}}>300^{\circ} \mathrm{C}$ and in the $\mathrm{Ar} / \mathrm{O}_{2}$ (3:2) atmosphere. $\mathrm{LCO}$ films were grown on Pt-coated Si wafers heated in the range $25-600{ }^{\circ} \mathrm{C}$ in an $\mathrm{Ar} / \mathrm{O}_{2}$ (ratio 3:1) gas flow rate of $12 \mathrm{sccm}$. Films deposited at $250{ }^{\circ} \mathrm{C}$ and annealed at $600{ }^{\circ} \mathrm{C}$ showed strong (104) orientation. An electrochemical test carried out under a current density of $10 \mu \mathrm{A} \mathrm{cm}^{-2}$ in the potential range of 4.2-3.0 V displayed responses depending on preparation conditions. Specific discharge capacities of 50, 42.5, and $30 \mu \mathrm{Ah} \mathrm{cm}^{-2} \mu \mathrm{m}^{-1}$ were obtained after 10 cycles, for films $25^{\circ} \mathrm{C}$-deposited and annealed at $600{ }^{\circ} \mathrm{C}, 250^{\circ} \mathrm{C}$-deposited and annealed at $600{ }^{\circ} \mathrm{C}$ and $600^{\circ} \mathrm{C}$-deposited, respectively [70]. The structure of LCO films deposited on Pt/Ti/quartz glass at different substrate temperatures in the range $25-500{ }^{\circ} \mathrm{C}$ changed from amorphous to strongly 
oriented (003) texture. The films grown at $T_{\mathrm{S}}=400{ }^{\circ} \mathrm{C}$ displayed the well-defined discharge voltage plateau of crystallized LCO at 3.9 V and delivered an initial specific capacity of $54.5 \mu \mathrm{Ah} \mathrm{cm}^{-2} \mu \mathrm{m}^{-1}$ [76]. The multilayer system $\mathrm{Si}$ (substrate)/ $/ \mathrm{Si}_{3} \mathrm{~N}_{4} / \mathrm{TiO} \times \mathrm{Pt} / \mathrm{LCO}$ has been fabricated, in which $\mathrm{Si}_{3} \mathrm{~N}_{4}$ is used as a barrier against the $\mathrm{Li}$ diffusion into silicon and $\mathrm{TiO}_{\mathrm{x}}$ is an adhesion layer with an optimum thickness of 25-45 nm [77]. Note that $\mathrm{SiO}_{2}$ between $\mathrm{LiCoO}_{2}$ and $\mathrm{Si}$ can work as a solid-state electrolyte allowing transport of $\mathrm{Li}$ ions and trap $\mathrm{Li}$ ions when external voltage is removed thus increasing device retention. Recently, $\mathrm{Hu}$ et al. investigated the effect of the $\mathrm{SiO}_{2}$ thickness on the properties of the $\mathrm{Pt} / \mathrm{LiCoO}_{2} / \mathrm{SiO}_{2} / \mathrm{Si}$ stacks demonstrating the Li trapping mechanism [78].

The gravimetric density and the porosity of films are important parameters playing a major role for the transport of $\mathrm{Li}$ ions in the cathode material. Experimental results have evidenced the dependence of the density on the sputter pressure and film thickness $[59,79]$. The film density is currently determined by fitting the $X$-ray reflectivity measurements. Ziebert at al. [59] reported an increase of the density from 4.34 to a maximum value of $4.75 \mathrm{~g} \mathrm{~cm}^{-3}$ for increasing pressure from 0.15 and $1 \mathrm{~Pa}$, respectively for $3-\mu \mathrm{m}$ thick LCO films. At pressure of $10 \mathrm{~Pa}$, the density strongly decreased to $3.5 \mathrm{~g} \mathrm{~cm}^{-3}$. SEM images displayed visible gaps and voids, giving evidence of an increase of the porosity. For 100-nm thick films, the decrease of the density is less dramatic, at $10 \mathrm{~Pa}$ a value of $4.2 \mathrm{~g} \mathrm{~cm}^{-3}$ was measured.

Due to the difference of the atomic weights between $\mathrm{Li}$ and $\mathrm{Co}$, the $\mathrm{Li} / \mathrm{Co}$ ratio is sensitive to the $\mathrm{rf}$ power [58]. LCO films with $\mathrm{Li} / \mathrm{Co}$ close to 1 was obtained with a small fraction of $\mathrm{O}_{2}$ in the mixed gas $(\leq 25 \%)$ under working pressure of $2 \mathrm{~Pa}$ using a sputter power in the range $75-100 \mathrm{~W}$. Higher sputter power produces a reduction of the compositional Li/Co ratio. Pan and Yang reported the effects of the radio-frequency sputtering powers $(80-200 \mathrm{~W})$ on the micro-structures and electrochemical properties of LCO thin film electrodes. LCO films, grown on Pt-wafer substrates kept at $55^{\circ} \mathrm{C}$ and at high sputtering power of $200 \mathrm{~W}$, had (101)-oriented with big grains of $150 \mathrm{~nm}$ in size and exhibited a specific capacity of $61 \mu \mathrm{Ah} \mathrm{cm}^{-2} \mu \mathrm{m}^{-1}$ when discharged at a constant current of $20 \mu \mathrm{A} \mathrm{cm}^{-2}$ between 4.2 and 3.0 V [68]. Similar studies were carried out by Jeon et al. [80] showing a specific capacity of $\sim 59 \mu \mathrm{Ah} \mathrm{cm}^{-2} \mu \mathrm{m}^{-1}$ taken at $30 \mu \mathrm{A} \mathrm{cm}^{-2}$ for the LCO films deposited on stainless-steel substrate at $150 \mathrm{~W}$ sputtering power in an $\mathrm{Ar} / \mathrm{O}_{2}$ mixture of 9:1. Pracharova et al. [81] stated that neither the substrate temperature nor the substrate material influences the Li/Co atomic ratio in LCO thin films deposited on $\mathrm{Si} / \mathrm{SiO}_{2} / \mathrm{Ti} / \mathrm{Au}$ substrate, while the radio-frequency discharge power is an important parameter to control the stoichiometry. For a sputter power of $60 \mathrm{~W}$ (i.e., $3.06 \mathrm{~W} \mathrm{~cm}{ }^{-2}$ ), the films were stoichiometric but an unfavorable (003) orientation was observed by X-ray diffraction and Raman spectroscopy. Using a low power of $25 \mathrm{~W}$, Rao et al. [82] prepared out-of-stoichiometric $\mathrm{Li}_{\mathrm{x}} \mathrm{CoO}_{\mathrm{y}}$ films with $x<1$ and $y>2$. Electrical conductivity measurements showed that the film $\mathrm{Li}_{0.8} \mathrm{CoO}_{2.7}$ is metallic, which can be beneficial for its role as a cathode material but contains $\mathrm{Co}_{3} \mathrm{O}_{4}$ impurity phase, which is detrimental.

The effect of the sputter gas mixture on the LCO thin film composition has been widely demonstrated. For sputter gas consisting of $100 \% \mathrm{Ar}$, the $\mathrm{Li} / \mathrm{Co}$ ratio was found to be 0.88 [40] or 1:0 \pm 0.1 [83]. Park et al. [84] studied the influence of the pressure (from 0.4 to $2.4 \mathrm{~Pa}$ ) on the LCO thin film properties and reported the highest discharge capacities for 2.4 Pa but did not test higher pressures. Ziebert et al. [59] investigated the composition of LCO thin films sputtered in Ar atmosphere. Figure 8 presents the variation of the lithium and oxygen content as a function of the Ar pressure in the range $0.15-25 \mathrm{~Pa}$. Elemental analyses carried out by inductive coupled plasma (ICP) show lithium excess for deposition at low pressures $\left(P_{\mathrm{Ar}} \leq 1 \mathrm{~Pa}\right)$ and oxygen deficiency in the range 0.5-1.0 $\mathrm{Pa}$. An annealing treatment in $\mathrm{Ar} / \mathrm{O}_{2}$ (4.5:5) atmosphere of $10 \mathrm{~Pa}$ at temperatures between 100 and $600{ }^{\circ} \mathrm{C}$ for $3 \mathrm{~h}$ compensate for the oxygen deficiency.

For oxygen-rich $\mathrm{Ar} / \mathrm{O}_{2}$ mixes of 1:10, 1:2, or 1:1, the $\mathrm{Li} / \mathrm{Co}$ ratio was reported to be $0: 8 \pm 0: 08$ $(\mathrm{O} / \mathrm{Co}=2.7)$ [85], $0.4(\mathrm{O} / \mathrm{Co}=1.92)$ [49], or 1:15 $\pm 0: 02(\mathrm{O} / \mathrm{Co}=2.2)$ [39], respectively. Bouwman et al. [69] prepared submicrometer LCO films deposited on (100)-oriented Si substrate using a stoichiometric target in rf-sputtering conditions of $T_{\mathrm{s}}=300{ }^{\circ} \mathrm{C}$, with background pressure of $0.7 \mathrm{~Pa}$ for the $\mathrm{Ar} / \mathrm{O}_{2}$ mixture in 3:1 ratio. At a growth rate of $0.5 \mathrm{~nm} \mathrm{~min}{ }^{-1}$ and after annealing at $600{ }^{\circ} \mathrm{C}$ for $3 \mathrm{~h}$, the films 
were preferentially oriented with their (110) planes parallel to the substrate surface. However, an O/Co ratio of 2.02 was reported. The use of only argon in a conventional sputtering process may create cracks in LCO films. In thick films, distinct columnar structures appeared after annealing, which must be eliminated, because they result in lower film density and formation of cracks limiting the lithium diffusion. Mixing $\mathrm{O}_{2}$ with Ar during the deposition allows the fabrication of thick films with better morphology, good stoichiometry, and battery performance as a result of the presence of oxygen improving the film nucleation and growth. Park et al. [84] investigated the influence of sputtering gas pressure on the 200-nm thick $\mathrm{LiCoO}_{2}$ thin films prepared from a 4 inch target sputtered at $200 \mathrm{~W}$ under operating $\mathrm{Ar} / \mathrm{O}_{2}$ gas ratio of 8:2 maintained at pressure in the range of 0.3-1.8 Pa. Films exhibiting the best performance were annealed at a temperature that does not exceed $400{ }^{\circ} \mathrm{C}$. The higher value of specific capacity (ca. $38 \mu \mathrm{Ah} \mathrm{cm}^{-2} \mu \mathrm{m}^{-1}$ ) is obtained for film grown at pressure of 1.3 Pa. The matter transport through Ar plasma in LCO thin films sputtering was analyzed using the Monte Carlo method [81]. Stable Li/Co ratios have been obtained at $5 \mathrm{~Pa}$ pressure and for the substrate-target distance in the range of $5-11 \mathrm{~cm}$.

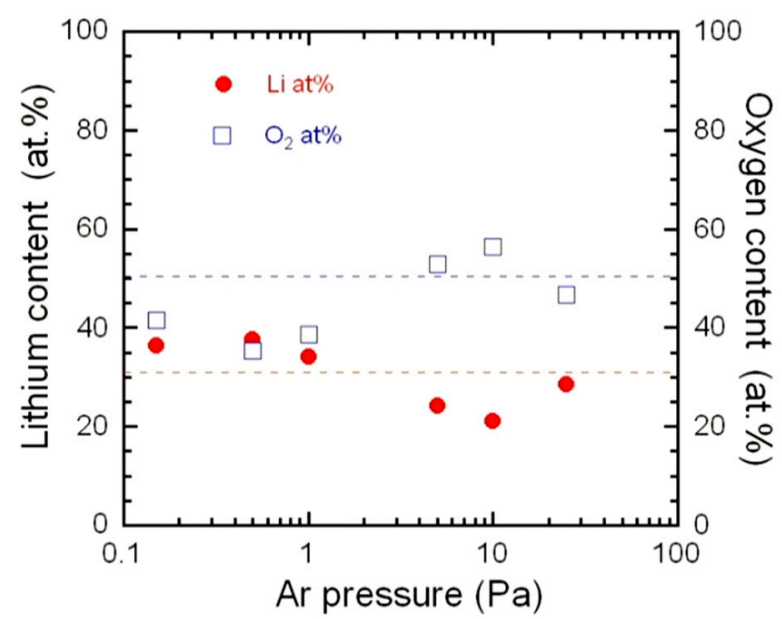

Figure 8. Variation of the lithium and oxygen content as a function of the Ar pressure for LCO thin films deposited on (100)-oriented Si substrates. Reproduced with permission from [59]. Copyright 2010 Elsevier.

Among the various ways of improvement of the growth process of crystalline LCO thin films, the use of a substrate bias has been proposed as the key parameter for decreasing the use of annealing treatment. The influence of the substrate bias on the LCO film crystallinity was recognized since 2005. The effect of substrate biases $\left(V_{\mathrm{b}}\right)$ in the range $0-100 \mathrm{~V}$ has been investigated on the morphology and electrochemical performance of LCO thin films (350 nm thick) deposited on $\mathrm{Si}(100) / \mathrm{SiO}_{2} / \mathrm{Ti} / \mathrm{Pt}$ under $\mathrm{Ar} / \mathrm{O}_{2}$ (45:5) gas flow at a working pressure of $0.5 \mathrm{~Pa}$ using a sputtering power of $200 \mathrm{~W}$ [86]. At $V_{\mathrm{b}}=0 \mathrm{~V}$, the XRD patterns showed tiny (003) and (006) peaks that disappeared with application of $V_{\mathrm{b}}$ in favor of the (101) Bragg line. The LCO films deposited at $V_{\mathrm{b}}=-50 \mathrm{~V}$ had an average grain size of $4.9 \mathrm{~nm}$ (density of $5.16 \mathrm{~g} \mathrm{~cm}^{-3}$ ), while at $V_{\mathrm{b}}=-70 \mathrm{~V}$ the presence of $\mathrm{Co}_{3} \mathrm{O}_{4}$ was detected. The charge-discharge tests carried out at a $1 \mathrm{C}$ rate in the voltage range of 3.0-4.3 V displayed a specific capacity of $60 \mu \mathrm{Ah} \mathrm{cm}^{-2} \mu \mathrm{m}^{-1}$. The cycling performance of a Li/LiPON/LCO/Pt solid-state microbattery is shown in Figure 9. The -50 V-biased electrode showed a good capacity retention of $90 \%$ after 100 cycles.

In 2011, Navone et al. [24] lowered the annealing temperature to $500^{\circ} \mathrm{C}$ by the optimization of bias sputtering at $-50 \mathrm{~V}$ (with $\mathrm{Ar} / \mathrm{O}_{2}$ ratio 3:1) that produced 0.5- $\mu \mathrm{m}$ thick crystalline deposits without any trace of the cubic phase. Such films delivered a specific capacity of $50 \mu \mathrm{Ah} \mathrm{cm}^{-2} \mu \mathrm{m}^{-1}$ after 140 cycles at $10 \mu \mathrm{A} \mathrm{cm}^{-2}$ current density. Next, the same group of research recognized that the crystallinity is not only controlled by the annealing temperature and the bias voltage but also by the pressure of the gas 
mixture. LCO films deposited by RFS onto Al substrates and post-annealed treated at $500{ }^{\circ} \mathrm{C}$ in air for $2 \mathrm{~h}$ show various morphologies and structures as a function of the operating $\mathrm{Ar} / \mathrm{O}_{2}$ gas pressure ranging from 0.55 to $3 \mathrm{~Pa}$. Variation of gas mixture, gas pressure, substrate bias promoted the relative amount of LCO phase mixture, i.e., mixture of the layered HT-LCO and cubic LT-LCO.

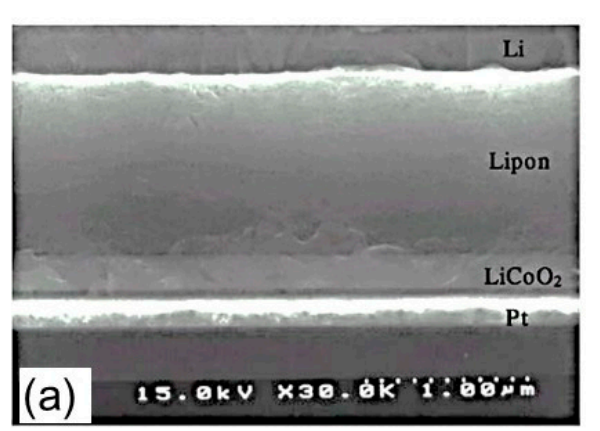

Figure 9. (a) Cross-section image of all solid-state Li/LiPON/LCO/Pt microbattery. (b) Cyclability as a function of the substrate biases used during the rf sputtering process of the LCO cathode film. Reproduced with permission from [86]. Copyright 2005 Elsevier.

Optimized films were produced at $3 \mathrm{~Pa}$ in an $\mathrm{Ar} / \mathrm{O}_{2}$ gas mixture of 3:4 delivering a high specific capacity of $67 \mu \mathrm{Ah} \mathrm{cm}^{-2} \mu \mathrm{m}^{-1}$ at C/5 rate but these studies were carried out in a liquid electrolyte only [87]. Taking the advantage of a high-rate bias, LCO films were tested in a non-aqueous electrolyte cell [88] and, finally, a rf-sputter-deposited microbattery LCO/LiPON/Li was fabricated on the $\mathrm{Si} / \mathrm{SiO}_{2} / \mathrm{Sn}_{3} \mathrm{~N}_{4} / \mathrm{Ti} / \mathrm{Au}$ substrate that delivered an initial specific capacity of $49 \mu \mathrm{Ah} \mathrm{cm}^{-2} \mu \mathrm{m}^{-1}$ at $10 \mu \mathrm{A} \mathrm{cm}{ }^{-2}$ current density and showed a capacity retention of $82 \%$ after 800 cycles [25].

Annealing is requested for the formation of well-crystallized films with preferential (104) or (101) orientation. Sufficient annealing temperature is also especially important in order to get the HT-LCO phase that avoids poor cyclability. However, heat treatment at temperature as low as $500{ }^{\circ} \mathrm{C}$ could be preferable to maintain a good adhesion on the substrate. The drawbacks of annealing at temperatures greater than $700{ }^{\circ} \mathrm{C}$ producing cracks and voids, i.e., micro-short paths, has been also mentioned [86,89]. The combination of a substrate temperature of $250{ }^{\circ} \mathrm{C}$ and annealing process under $\mathrm{O}_{2}$ ambient at $650{ }^{\circ} \mathrm{C}$ leads to LCO films with the characteristic (104)-preferred plane [90]. Rapid thermal annealing (at $650^{\circ} \mathrm{C}$ for $15 \mathrm{~min}$ was proposed. LCO films were grown on Pt-coated Si wafers heated in the range $25-600{ }^{\circ} \mathrm{C}$ in an $\mathrm{Ar} / \mathrm{O}_{2}$ (ratio 3:1) gas flow rate of $12 \mathrm{sccm}$. Films deposited $250{ }^{\circ} \mathrm{C}$ and annealed at $600{ }^{\circ} \mathrm{C}$ showed strong (104) orientation. An electrochemical test carried out under a current density of $10 \mu \mathrm{A} \mathrm{cm}{ }^{-2}$ in the potential range of 4.2-3.0 $\mathrm{V}$ displayed responses depending on preparation conditions. Specific discharge capacities of 50,42.5, and $30 \mu \mathrm{Ah} \mathrm{cm}^{-2} \mu \mathrm{m}^{-1}$ were obtained after 10 cycles, for films $25^{\circ} \mathrm{C}$-deposited and annealed at $600{ }^{\circ} \mathrm{C}, 250{ }^{\circ} \mathrm{C}$-deposited and annealed at $600{ }^{\circ} \mathrm{C}$ and $600{ }^{\circ} \mathrm{C}$-deposited, respectively [70]. Well-crystallized sputtered LCO films (500 nm thick) were obtained after annealing at different temperatures $\left(400-700{ }^{\circ} \mathrm{C}\right)$ for $1 \mathrm{~h}$ in $\mathrm{O}_{2}$ ambient. The films were deposited at the rate of $0.08 \mathrm{~nm} \mathrm{~s}^{-1}$ at room temperature on NASICON-type electrolyte $\mathrm{Si}$ - and Ge-doped $\mathrm{Li}_{1.3} \mathrm{Al}_{0.3} \mathrm{Ti}_{1.7}\left(\mathrm{PO}_{4}\right)_{3}(\mathrm{LATP})$ substrates in a working Ar atmosphere kept at $0.5 \mathrm{~Pa}$ [26]. It appeared that films displayed large voids and a triggered nucleation of a face-centered cubic (fcc) phase for annealing at $700{ }^{\circ} \mathrm{C}$. Films annealed at $500{ }^{\circ} \mathrm{C}$ showed strong crystallographic (101) texture with layer planes aligned nearly normal to the substrate. Electrochemical tests of the cell $\mathrm{Li} / \mathrm{LiPON} / \mathrm{LATP} / \mathrm{LCO} / \mathrm{Pt}$, where $1-\mu \mathrm{m}$-thick LiPON acts as a buffer layer to avoid degradation of the LATP in contact with $\mathrm{Li}$ anode, were carried out between 3.3 and $4.2 \mathrm{~V}$ at a $0.01 \mathrm{C}$ rate. This cell exhibited an initial specific discharge capacity of $40 \mu \mathrm{Ah} \mathrm{cm}^{-2} \mu \mathrm{m}^{-1}$ that decreased to $15 \mu \mathrm{Ah} \mathrm{cm}^{-2} \mu \mathrm{m}^{-1} \mathrm{after}$ 50 cycles. Xie et al. [91] show that amorphous LCO films deposited on NASICON glass ceramics $\mathrm{Li}_{1+x+y} \mathrm{Al}_{\mathrm{x}} \mathrm{Ti}_{2-\mathrm{x}} \mathrm{Si}_{\mathrm{y}} \mathrm{P}_{3-\mathrm{y}} \mathrm{O}_{12}(\mathrm{LATSP})$ at $\mathrm{T}_{\mathrm{s}}<180{ }^{\circ} \mathrm{C}$. An initial discharge capacity of $210 \mathrm{mAh} \mathrm{g}^{-1}$ was 
delivered by as-deposited LCO thin films ( $0.5 \mu \mathrm{m}$ thick) on LATSP in $\mathrm{Ar} / \mathrm{O}_{2}(7: 3)$ at a power of $100 \mathrm{~W}$. A rapid-thermal annealing (RTA) process at $700{ }^{\circ} \mathrm{C}$ under flowing oxygen gas (for $20 \mathrm{~min}$ ) was shown to be a successful method to obtain LCO thin films that consist of grains with (101) and (104) preferred orientations [92].

\section{Electrochemical Properties of Sputtered LCO Films}

\subsection{Charge-Discharge Behavior}

The maximum capacity (in Ah) of any lithium cell is largely determined by the amount of active material in the positive electrode. The specific capacity $Q_{\text {th }}$ in ampere-hour per mass $\left(\mathrm{Ah} \mathrm{kg}^{-1}\right)$, or equivalently in $\mathrm{mAh} \cdot \mathrm{g}^{-1}$ is obtained from the Faraday law [93]:

$$
Q_{t h}=\frac{1000 \times n F}{3600 \times M_{w}}=\frac{26.8}{M_{w}} \times n
$$

where $M_{\mathrm{W}}$ is the molecular mass of the "limiting" electrode material. With the transfer of $n=1 \mathrm{e}^{-}$per formula unit, the theoretical specific capacity of $\mathrm{LiCoO}_{2}\left(M_{\mathrm{w}}=97.87 \mathrm{~g} \mathrm{~mol}^{-1}\right)$ is $273.8 \mathrm{mAh} \cdot \mathrm{g}^{-1}$. Note that the reversible capacity, however, is limited to $140 \mathrm{mAh} \mathrm{g}^{-1}$ when $\mathrm{LiCoO}_{2}$ is cycled between 3 and $4.2 \mathrm{~V}$, corresponding to extracting and inserting about $0.5 \mathrm{Li}$ per $\mathrm{LiCoO}_{2}$. The relation between the gravimetric capacity, $Q_{m}$, of the material, and the volumetric capacity of a film, $Q_{f}$, is given by:

$$
Q_{f}=0.36 d Q_{m}
$$

where $Q_{m}$ is expressed in $\mathrm{mAh} \mathrm{g}^{-1}, Q_{f}$ is translated in $\mu \mathrm{Ah} \mathrm{cm}^{-2} \mu \mathrm{m}^{-1}$ (or $\mathrm{mC} \mathrm{cm}^{-2} \mu \mathrm{m}^{-1}$ ), and $d$ is the density of the material in $\mathrm{g} \mathrm{cm}^{-3}$. With a density of $5.06 \mathrm{~g} \mathrm{~cm}^{-3}$, the theoretical volumetric capacity of $\mathrm{LiCoO}_{2}$ is $137.8 \mu \mathrm{Ah} \mathrm{cm}^{-2} \mu \mathrm{m}^{-1}$ if porosity is ignored. Decreasing the film thickness implies a large electrode area or a limited capacity. A thin electrode film exhibiting high intercalation rates is expected to have a short diffusion pathway $L$ for the $\mathrm{Li}^{+}$ions according to Fick's law. In case the chemical reaction proceeds by a single-phase process, i.e., within a solid solution, the characteristic time $\tau_{\mathrm{sp}}$ for $\mathrm{Li}^{+}$ions to reach the surface of any active particle of dimension $L$ is given by:

$$
\tau_{s p}=\frac{L^{2}}{4 \pi D_{L i}}
$$

where $D_{\mathrm{Li}}$ is the chemical diffusion coefficient of moving ions in the host framework. However, Wang et al. [39] reported that thick electrodes $(>1 \mu \mathrm{m})$ could deliver higher current pulses. In this case, the preferred texture of the film plays a major role at the electrolyte-electrode interface. The electrochemical behaviors of sputtered thin-film LCO cathode were characterized under high-voltage conditions in microbatteries using either an organic electrolyte $\left(1 \mathrm{~mol} \mathrm{~L}^{-1} \mathrm{LiPF}_{6}\right.$ in ethylene-dietylene carbonate) or a LiPON solid film electrolyte. One of the first attempts show that, even annealed at $600{ }^{\circ} \mathrm{C}$ in air, the $0.2-\mu \mathrm{m}$ thick $\mathrm{LCO}$ films deposited with a low power of $50 \mathrm{~W}$ on $\mathrm{SnO}_{2}$-coated glass under working pressure $0.7 \mathrm{~Pa}$ have only delivered a discharge capacity of $114 \mathrm{mC} \mathrm{cm}^{-2} \mu \mathrm{m}^{-1}$ (in the voltage range 4.1-3.0 V) due to the mixed $\mathrm{LiCoO}_{2}+\mathrm{Li}_{1.47} \mathrm{CO}_{3} \mathrm{O}_{4}$ crystalline phase [94]. Liao and Fung [63] obtained a first discharge capacity of $\sim 42, \sim 50$, and $\sim 61 \mu \mathrm{Ah} \mathrm{cm} \mathrm{cm}^{-2} \mu \mathrm{m}^{-1}$ at a discharge rate of $10 \mu \mathrm{A} \mathrm{cm}{ }^{-2}$ in the potential range $4.25-3.0 \mathrm{~V}$ for LCO film $\left(1.3 \mu \mathrm{m}\right.$ thick) annealed at 500,600 , and $700{ }^{\circ} \mathrm{C}$ for $2 \mathrm{~h}$, respectively. These films originally deposited on $\mathrm{Pt} / \mathrm{Ti}(20 \mathrm{~nm}) / \mathrm{SiO}_{2}(600 \mathrm{~nm}) /(100) \mathrm{Si}$ substrate heated at $250{ }^{\circ} \mathrm{C}$ under $P_{\mathrm{O}_{2}}=0.5-5.0 \mathrm{~Pa}$ (gas flow rate of $12 \mathrm{sccm}$, power of $100 \mathrm{~W}$ and $d_{s t}=40 \mathrm{~mm}$ ) had a nanocrystalline structure with (104) out-of-plane orientation.

Taking into account the advantage of the LiPON stability up to $5.5 \mathrm{~V} \mathrm{vs}$. $\mathrm{Li}+/ \mathrm{Li}$, the galvanostatic charge-discharge (GCD) measurements were carried out in the voltage range of 3.0-5.0 $\mathrm{V}$ at a current density of $10 \mu \mathrm{A} \mathrm{cm}^{-2}$ [95]. Figure 10a shows the variation of the discharge capacity with the charge cutoff voltage for a discharge voltage limit fixed at $3.0 \mathrm{~V}$. The $1.2-\mu \mathrm{m}$ thick LCO film can sustain a 
capacity of $\sim 85 \mu \mathrm{Ah} \mathrm{cm}^{-1} \mu \mathrm{m}^{-1}\left(170 \mathrm{mAh} \mathrm{g}^{-1}\right)$, which correspond at $x=0.63 \mathrm{Li}$ extracted when the cell is charged at $4.4 \mathrm{~V}$. However, upon cycling to further voltage $(>4.4 \mathrm{~V})$, a two-phase reaction $\left(\mathrm{CoO}_{2}\right.$ and $\mathrm{Li}_{\mathrm{x}} \mathrm{CoO}_{2}$ phases) associated with the variation of the c-lattice parameter of $3.2 \%$ induced an increase of cell resistance and capacity fades (Figure 10b). The formation of cracks appeared for the LCO film is cycled to $5 \mathrm{~V}$ due to the overcharge process.

Noh et al. compared the microstructure and electrochemical performance of sputtered $\mathrm{LiCoO}_{2} / \mathrm{LiNiO}_{2}$ multilayer thin film cathode with that of $\mathrm{LiCoO}_{2}$ single-layer [96]. Using an $\mathrm{Ar} / \mathrm{O}_{2}$ gas mixture (4:1) at a flow rate of $150 \mathrm{sccm}$ with a pressure maintained at $0.3 \mathrm{~Pa}$, both electrodes deposited at $T_{\mathrm{S}}=65^{\circ} \mathrm{C}$ had the (003)-preferred orientation. The initial discharge capacity of the multi-layer electrode was $\sim 53 \mu \mathrm{Ah} \mathrm{cm} \mathrm{cm}^{-2} \mu \mathrm{m}^{-1}$ at a current density of $10 \mu \mathrm{A} \mathrm{cm}^{-2}$ in the potential range of 3.0-4.2 $\mathrm{V}$, approximately $30 \%$ larger than the single LCO electrode. Via in situ measurements, Cho et al. [71] investigated the thermal conductivity of sputtered $\mathrm{Li}_{\mathrm{x}} \mathrm{CoO}_{2}$ films electrochemically delithiated in the range $1.0 \leq x \leq 0.6$. LCO films (500-nm thick) were deposited by reactive sputtering at ate of $0.8 \mathrm{~nm} \mathrm{~min}{ }^{-1}$ on $c$-plane oriented sapphire substrates coated with $\sim 100 \mathrm{~nm}$ of $\mathrm{SiO}_{2}$ and an $\sim 80 \mathrm{~nm} \mathrm{Al}$ layer as current collector. They were randomly textured after an annealing process at $500{ }^{\circ} \mathrm{C}$ in air. During delithiation, the thermal conductivity decreases reversibly (from 5.4 to $3.7 \mathrm{~W} \mathrm{~m}^{-1} \mathrm{~K}^{-1}$ ) and the elastic modulus decreases as well from 325 to $225 \mathrm{GPa}$.
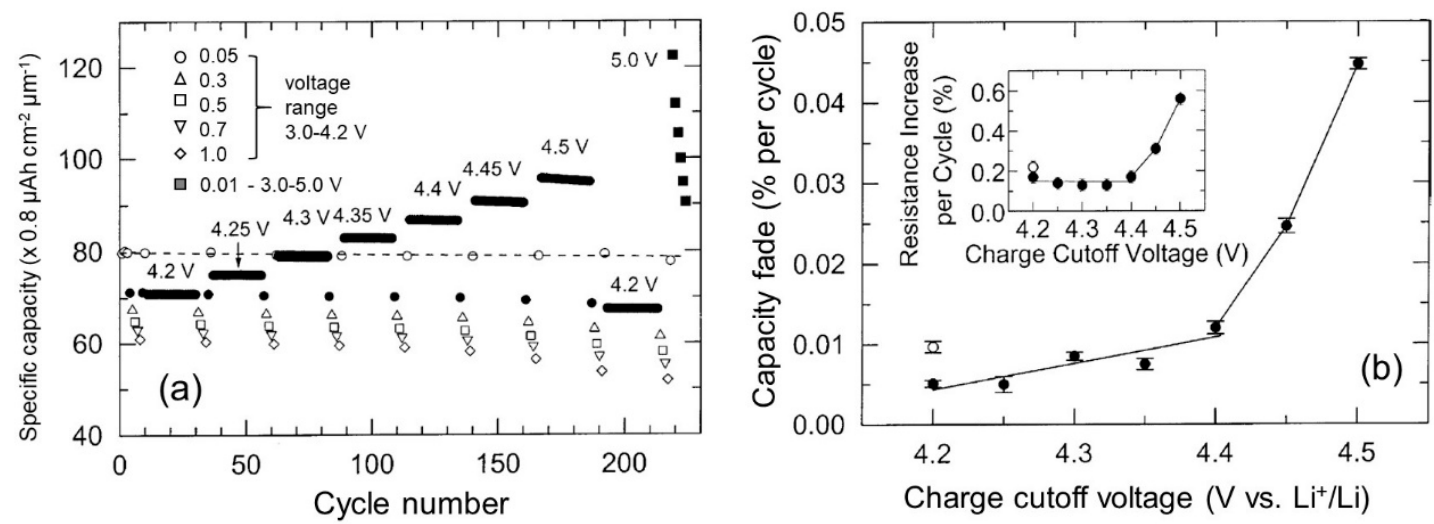

Figure 10. (a) The variation of the discharge capacity of sputtered LCO thin films with the charge cutoff voltage for a discharge voltage limit fixed at $3.0 \mathrm{~V}$ and a current density of $0.1 \mathrm{~mA} \mathrm{~cm}{ }^{-2}$ (black dots). The black squares are the capacities of cell cycled at $10 \mu \mathrm{A} \mathrm{cm}^{-2}$ in the potential range 3.0-5.0 V. Other opened symbols correspond to different discharge currents (in $\mathrm{mA} \mathrm{cm}^{-2}$ ) in the potential range 3.0-4.2 V. (b) Capacity fade per cycle as a function of the charge voltage cutoff. Inset presents the increase in cell resistance per cycle. Reproduced with permission from [95]. Copyright 2003 Elsevier.

\section{2. $\mathrm{Li}^{+}$Ion Diffusion}

The Li-ion chemical diffusion coefficients, $D_{\mathrm{Li}}$, were measured using various electrochemical methods, i.e., cyclic voltammetry (CV), galvanostatic intermittent titration technique (GITT), potentiostatic intermittent titration technique (PITT), and electrochemical impedance spectroscopy (EIS). In CV measurements, $D_{\mathrm{Li}}$ is determined from the Randles-Sevcik relation, which describes the influence of the sweep rate on the redox peak current, while other methods evaluate the composition dependence of $D_{\mathrm{Li}}$. The PITT and GITT methods rely on solving Fick's laws the variation of current (voltage) vs. time is measured after application of a potential (current) step to slightly modify the electrode composition of the electrode. In EIS measurements, the composition dependence of $D_{\mathrm{Li}}$ is estimated from the Warburg impedance related with the straight line of $45^{\circ}$ slope of the Nyquist diagram. The $D_{\mathrm{Li}}$ values are considered to be more reliable when obtained from GITT and PITT methods [67]. However, the disparate values of $D_{\mathrm{Li}}$ are often due to a poor evaluation of the actual surface area of the electrode. It is recommended to use Brunauer-Emmett-Teller (BET) surface measurements. 
The influence of the diffusion plane orientation on electrochemical properties of thin film LCO electrodes has been pointed out by several authors $[67,79,97]$. Submicrometer LCO films deposited on Si substrates exhibited a strong $a$-axis orientation, which favors the intercalation rate and cycling efficiency. However, Bouwman et al. reported an intercalation rate hindered by a large charge-transfer resistance and phase boundary motion rather than the diffusion-limited behavior currently observed in LCO crystal [97]. Xie et al. $[67,79]$ reported the $\mathrm{Li}^{+}$ion kinetics in three $\mathrm{LCO}$ thin films sputtered for different duration $\left(t_{\mathrm{d}}\right)$ of 30,60 , and 120 min on polished $\mathrm{Al}_{2} \mathrm{O}_{3}$ substrates covered with a $900 \mathrm{~nm}$ thick $\mathrm{Au}$ layer. A $0.31-\mu \mathrm{m}$ thick $\mathrm{LiCoO}_{2}$ thin film (sputtered for $t_{\mathrm{d}}=30 \mathrm{~min}$ ) showed a high (003) orientation, while a $1.35-\mu \mathrm{m}$ thick film (sputtered for $t_{\mathrm{d}}=120 \mathrm{~min}$ ) exhibited high (104) orientation. $\mathrm{CV}$ measurements showed that the peak current $\left(I_{\mathrm{p}}\right)$ follows a linear relationship with the square root of the scan rate $\left(v^{1 / 2}\right)$ indicating a diffusion-controlled process. Thus, $D_{\mathrm{Li}}$ can be calculated using the Randles-Sevcik relation $I_{p}=f\left(v^{1 / 2}\right)$ :

$$
D_{L i}=\frac{5 R T}{n^{3} F^{3} A^{2} C_{L i}^{2}} \frac{I_{p}^{2}}{v}
$$

where $R$ and $F$ are the usual constants, $T$ is the absolute temperature, $A$ is the surface area of the electrode, and $C_{\mathrm{Li}}$ is the concentration of $\mathrm{Li}$ in the electrode. The (104)-oriented film exhibited a larger $D_{\mathrm{Li}}$ value of $7.7 \times 10^{-12} \mathrm{~cm}^{2} \mathrm{~s}^{-1}$ than $6.4 \times 10^{-13} \mathrm{~cm}^{2} \mathrm{~s}^{-1}$ for the (003) oriented thin film. Note that these values are "apparent" diffusion coefficients because the compositional dependence of $D_{\mathrm{Li}}$ cannot be determined by the CV technique. However, the PITT method based on solving the Fick's diffusion equation determines $D_{\mathrm{Li}}$ as a function of $x(\mathrm{Li})$ in $\mathrm{Li}_{x} \mathrm{CoO}_{2}$ by recording the time dependence of the transient current $\left(I_{t}\right)$ when a potential step is applied to the film:

$$
D_{L i}=\frac{d L n\left(I_{p}\right)}{d t} \frac{4 L^{2}}{\pi^{2}}
$$

where $L$ is the thickness of the film. The compositional dependence of $D_{\mathrm{Li}}$ calculated using Equation (5) is presented in Figure 11, which displays the structural domains of the $\mathrm{LiCoO}_{2}$ electrode according the phase diagram reported by Bouwman et al. [97].

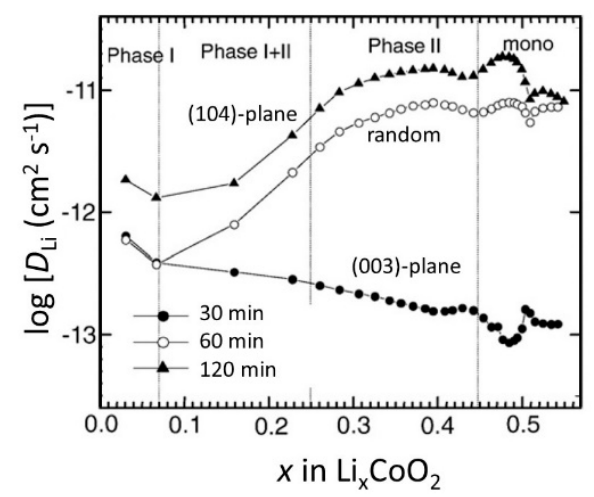

Figure 11. Compositional dependence of the $\mathrm{Li}^{+}$ion diffusion coefficients in LCO thin films sputtered at different durations, as measured using the potentiostatic intermittent titration technique (PITT) method. Reproduced with permission from [79]. Copyright 2008 Elsevier.

Liao et al. [58] investigated the effect of various rf-sputtering parameters on the $\mathrm{Li}^{+}$ion diffusion coefficient if LCO films deposited on Pt-coated Si wafers. The $700{ }^{\circ} \mathrm{C}$-annealed film showing good crystallinity with (104) preferred orientation exhibit a high discharge capacity of 61 and $56 \mu \mathrm{Ah} \mathrm{cm}{ }^{-2} \mu \mathrm{m}^{-1}$ at a discharge rate of 10 and $50 \mu \mathrm{A} \mathrm{cm}^{-2}$, respectively, while the $500{ }^{\circ} \mathrm{C}$-annealed film displays a discharge capacity of $35 \mu \mathrm{Ah} \mathrm{cm}^{-2} \mu \mathrm{m}^{-1}$ at a discharge rate of $50 \mu \mathrm{A} \mathrm{cm}^{-2}$ [58]. The diffusion coefficient of $\mathrm{Li}^{+}$ions $\left(D_{\mathrm{Li}}\right)$ in LCO thin films appears as a two-step behavior with a decrease 
of almost two orders of magnitude around $3.9 \mathrm{~V}$ (Figure 12). Due to the higher crystallinity, $D_{\mathrm{Li}}$ increases with annealing temperature $\left(T_{\mathrm{a}}\right)$ and indicates a stable layered structure for $T_{\mathrm{a}}=700^{\circ} \mathrm{C}$.

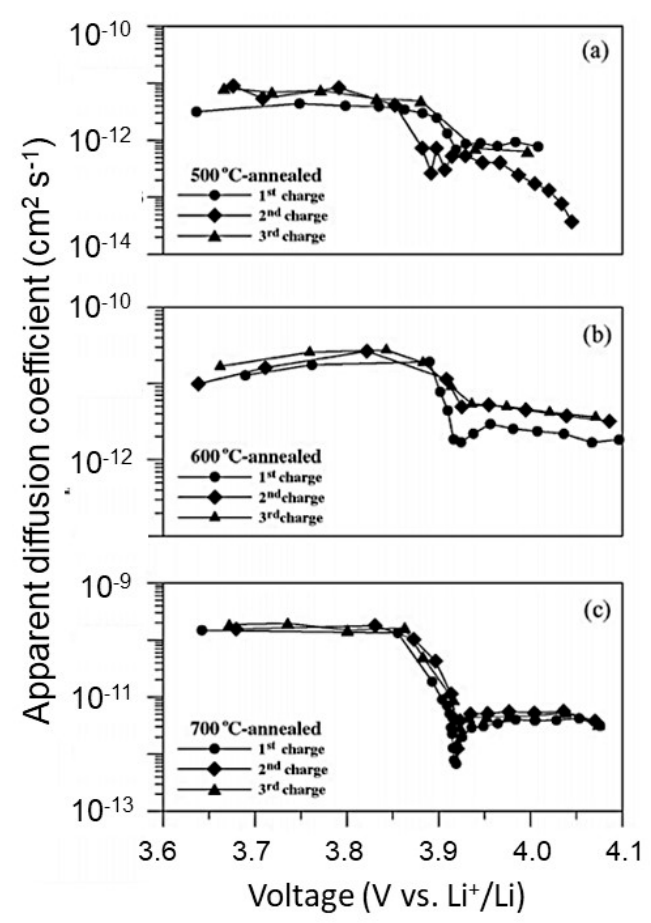

Figure 12. $D_{\mathrm{Li}}$ as a function of cell voltage obtained from different charging cycles from the galvanostatic intermittent titration technique (GITT) for (a) $500{ }^{\circ} \mathrm{C}$-annealed, (b) $600{ }^{\circ} \mathrm{C}$-annealed, and (c) $700{ }^{\circ} \mathrm{C}$-annealed $\mathrm{HT}-\mathrm{LiCoO}_{2}$ films. Reproduced with permission from [58]. Copyright 2007 Elsevier.

\subsection{Solid-Electrolyte/Electrode Interface}

Numerous studies have been devoted to the behavior of the solid-electrolyte/electrode interface (SEI layer). The sputtered LCO/LiPON interface was investigated step-by-step by photoelectron $X$-ray-induced spectroscopy. The SEI layer, $\sim 10 \AA$ thick, contains new nitrogen-containing species, i.e., $\mathrm{NO}_{2}{ }^{-}$and $\mathrm{NO}_{3}{ }^{-}$[98]. The reactivity of $\mathrm{LCO}$ thin films with a non-aqueous electrolyte, i.e., $1 \mathrm{~mol} \mathrm{~L}^{-1}$ $\mathrm{LiClO}_{4}$ in propylene carbonate (PC), has been investigated by several electroanalytical techniques, i.e., electrochemical impedance measurement, in situ Fourier transform infrared (FTIR) spectroscopy, and X-ray photoelectron spectroscopy (XPS). The formation of decomposition products, i.e., the organic surface layer, greatly depends on the crystal orientation and amount of the impurity $\left(2 \mathrm{~mol} \% \mathrm{Co}_{3} \mathrm{O}_{4}\right.$ cubic phase). The best electrochemical performance $\left(229 \mathrm{mC} \mathrm{cm}^{-2} \mu \mathrm{m}^{-1}\right.$ in the voltage range $\left.3.5-4.4 \mathrm{~V}\right)$ is attained for $\mathrm{LCO}$ films sputtered on Au substrate $\left(T_{\mathrm{s}}=300{ }^{\circ} \mathrm{C} ; \mathrm{Ar} / \mathrm{O}_{2}\right.$ of $2: 1 ;$ and $\left.\Theta_{\mathrm{dr}}=8 \mathrm{~nm} \mathrm{~min}{ }^{-1}\right)$ with a (003) plane perpendicular to the substrate [99]. In the following experiments, the decomposition of the aprotic solvent mixture ethylene carbonate (EC) + diethyl carbonate (DEC) was studied by in situ FTIR spectroscopy. The electrochemical oxidations of EC:DEC occurred on charge even at $3.8 \mathrm{~V}$ vs. $\mathrm{Li}^{+} / \mathrm{Li}$ [100]. Finally, the same group reported that atomic force microscopy (AFM) images showed the decomposed products appeared during charge on the LCO film surface, which disappeared from the surface upon discharge at the potential lower than $3.9 \mathrm{~V} \mathrm{vs.} \mathrm{Li}^{+} / \mathrm{Li}$ [101]. The electrolyte solution containing lithium bis(oxalate)borate (LiBOB) showed that the absorption of $\mathrm{BOB}$ anions occurs at the LCO film surface above $4 \mathrm{~V}$, preventing the decomposition of $\mathrm{PF}_{6}{ }^{-}$anions of the Li salt [102]. A dense $\mathrm{LiCoO}_{2}$ microcrystalline buffer layer ( $-20 \mathrm{~nm}$ thick) was deposited by rf-sputtering between the cathode $\left(\mathrm{LiNi}_{0.5} \mathrm{Co}_{0.2} \mathrm{Mn}_{0.3} \mathrm{O}_{2}\right)$ and solid electrolyte $\left(\mathrm{Li}_{7} \mathrm{Al}_{0.1} \mathrm{La}_{3} \mathrm{Zr}_{2} \mathrm{O}_{12}\right.$ pellet) in an all-solid-state lithium battery [103]. Due to the large interfacial specific surface area and the excellent interfacial stability of the LCO thin film, the interfacial energy barrier was only $97 \mathrm{meV}$ and the interfacial contact resistance was reduced by $1279 \Omega$. 


\subsection{Effect of Doping}

Due to the rhombohedral/monoclinic phase transition in $\mathrm{Li}_{\mathrm{x}} \mathrm{CoO}_{2}$, irreversible changes occur upon the charge process at $x \approx 0.5$, which limits the specific capacity to $140 \mathrm{mAh} \mathrm{g}^{-1}$ or $69 \mu \mathrm{Ah} \mathrm{cm}^{-2} \mu \mathrm{m}^{-1}$. Reportedly, one of the significant approaches to overcome this problem is lattice doping by either isovalent or aliovalent ions that results in the stable cycling at high voltages $(4.5 \mathrm{~V})[104,105]$. The influence of $\mathrm{Zr}$ doping on microstructural and electrochemical performance was investigated on a series of RF magnetron sputtered $\mathrm{LiZr}_{x} \mathrm{Co}_{1-x} \mathrm{O}_{2}$ thin films deposited on $\mathrm{Au} / \mathrm{Ti} / \mathrm{SiO}_{2} / \mathrm{Si}$ (100) substrates [106]. LCO films were deposited at the rate $13 \mathrm{~nm} \mathrm{~min}^{-1}$ on a substrate held at $T_{\mathrm{s}}=250{ }^{\circ} \mathrm{C}$ under $\mathrm{Ar} / \mathrm{O}_{2}$ (9:1) mix gas at working pressure of $0.6 \mathrm{~Pa}$ using a RF power of $130 \mathrm{~W}$. 1.2- $\mu \mathrm{m}$ thick LCO films exhibit a (108) preferential orientation. A slight increase in lattice parameters and c/a ratio (5.01 vs. 4.98 for pristine film) has been noticed for the $\mathrm{LiCo}_{0.98} \mathrm{Zr}_{0.02} \mathrm{O}_{2}$ films, confirming the introduction of $\mathrm{Zr}^{4+}$ ions $(0.72 \AA)$ in the host lattice. It is assumed that the presence of some $\mathrm{Co}^{2+}$ ions is due to a charge compensation effect. Electrochemical properties of doped-LCO films were investigated by CV and GCD. The narrow anodic/cathodic peak separation in cyclic voltammograms and the high $\mathrm{Li}^{+}$ion diffusion coefficient $\left(1.8 \times 10^{-11} \mathrm{~cm}^{2} \mathrm{~s}^{-1}\right)$ indicate an enhancement of kinetics of $\mathrm{Li}^{+}$ions by $\mathrm{Zr}$ doping. $\mathrm{The} \mathrm{Li} / / \mathrm{LiCo}_{0.98} \mathrm{Zr}_{0.02} \mathrm{O}_{2}$ cell with non-aqueous electrolyte exhibited an initial discharge capacity of $65 \mu \mathrm{Ah} \mathrm{cm}{ }^{-2} \mu \mathrm{m}^{-1}$ at a $1 \mathrm{C}$ rate with a fading of $3.8 \%$ after 80 cycles in the potential range $3-4.2 \mathrm{~V}$. The extension to a higher voltage was not explored in this work. Improved kinetics is also evidenced by the Nyquist plots shown in Figure 13. One observes a decrease of the charge-transfer resistance $\left(R_{\mathrm{ct}}\right)$ from $156 \Omega\left(\mathrm{LiCoO}_{2}\right)$ to $60 \Omega\left(\mathrm{LiCo}_{0.98} \mathrm{Zr}_{0.02} \mathrm{O}_{2}\right)$.

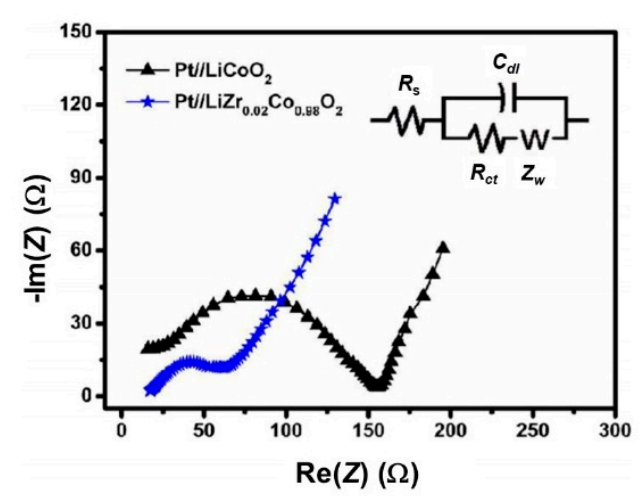

Figure 13. Nyquist plots of $\mathrm{Pt} / / \mathrm{LiCoO}_{2}$ and $\mathrm{Pt} / / \mathrm{LiCo}_{0.98} \mathrm{Zr}_{0.02} \mathrm{O}_{2}$ thin film cathodes. Inset displays the equivalent circuit model. Reproduced with permission from [106]. Copyright 2018 Elsevier.

Ti-doped LCO thin films were prepared using a sputter Li-enriched $\mathrm{LiCoO}_{2}$ mosaic target including Ti metal strips [107]. The chronoamperometry measurements revealed an enhanced capacity of $69 \mu \mathrm{Ah} \mathrm{cm}^{-2} \mu \mathrm{m}^{-1}\left(245 \mathrm{mC} \mathrm{cm}^{-2} \mu \mathrm{m}^{-1}\right)$ at a $1 \mathrm{C}$ rate that retained to $\sim 54 \mu \mathrm{Ah} \mathrm{cm}^{-2} \mu \mathrm{m}^{-1}$ at a $4 \mathrm{C}$ rate for $\mathrm{LiCo}_{0.98} \mathrm{Ti}_{0.02} \mathrm{O}_{2}$ thin film cathodes. The larger ionic radius of $\mathrm{Ti}^{4+}(0.605 \AA)$ than that of the $\mathrm{Co}^{3+}$ ion $(0.545 \AA$; in $\mathrm{CN}=6)$ provokes a slight elementary volume expansion of $0.6 \%$ and produces a pillaring effect that result in an enhancement of the $\mathrm{Li}^{+}$ion diffusion. Another reason for such a good electrochemical performance with aliovalent doping is based on the increasing $\mathrm{Co}^{3+}$ ions concentration and the lower concentration of Jahn-Teller $\mathrm{Co}^{4+}$ ions that cause spontaneous deformation and disrupt the LCO lattice on the charge process [108]. For a high doping, $y(\mathrm{Ti})>0.02$, the ion exchange provokes more cation disordering and the appearance of $\mathrm{Co}_{3} \mathrm{O}_{4}$ spinel impurities [109]. When prepared at $T_{\mathrm{S}}=250{ }^{\circ} \mathrm{C}$ using a $10 \%$ Li-enriched target, the Ti-doped LCO films exhibited a preponderant (104) orientation [110].

As a summary figure, the experimental results by Bates et al. [46] have clearly correlated the preferential growth of crystalline LCO films with sputtering conditions and resultant electrochemical properties. Figure 14 shows the variation of the discharge capacity (data points) and energy (dashed lines) against the current density for LCO thin-film electrodes with preferential orientation. Films 
were deposited on a $\mathrm{Si} / \mathrm{Co} / \mathrm{Pt}$ multilayer substrate in an $\mathrm{Ar}+\mathrm{O}_{2}$ gas mixture in a ratio of 3:1 at a total flow of $20 \mathrm{sccm}$ and a partial pressure of $2.7 \mathrm{pa}$. As an experimental fact, LCO films over $1-\mu \mathrm{m}$ thick deposited at $T_{\mathrm{s}} \leq 50{ }^{\circ} \mathrm{C}$ at a rate of $2 \mathrm{~nm} \mathrm{~min}^{-1}$ are $100 \%$ (003)-oriented grains, which demonstrates the lowest surface energy of the (003) plane. In contrast, $4-\mu \mathrm{m}$ thick LCO films deposited at $T_{\mathrm{s}}=70{ }^{\circ} \mathrm{C}$ at a rate of $1.3 \mathrm{~nm} \mathrm{~min}{ }^{-1}$ exhibit $84 \%$ (101)- and $16 \%$ (104)-oriented grains (0\% (003)); such a predominant texture was attributed to the large bulky strain energy in thick film [46]. As shown in Figure 14, the electrochemical features of thin electrode with (003)-oriented grains are greatly altered compared with the thicker LCO film. Of all these experiments, it appeared that the electrochemical performance of sputtered LCO films is a complex function of deposition conditions as demonstrated in this review paper.

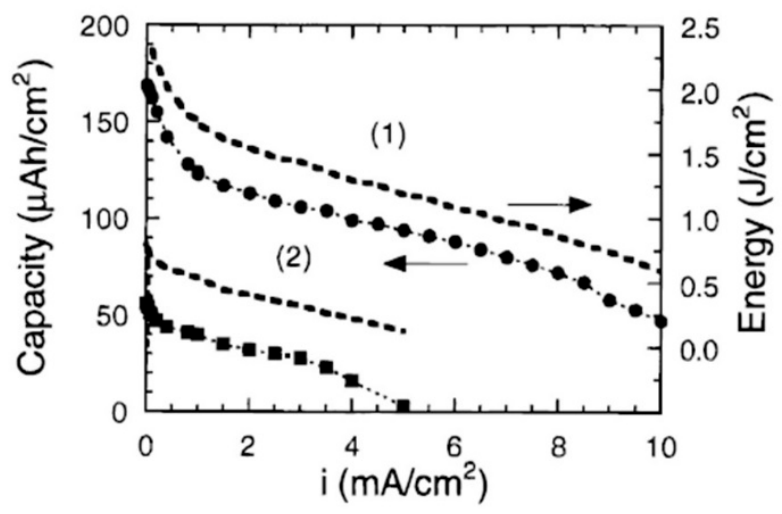

Figure 14. Variation of the discharge capacity (data points) and energy (dashed lines) against current density for LCO thin-film electrodes with preferential orientation. (1) 4- $\mu$ m thick film with (101) and (104)-oriented grains in a ratio 84:16. (2) 1 - $\mu \mathrm{m}$ thick film with $100 \%$ (003)-oriented grains. Reproduced with permission from [46]. Copyright 2000 The Electrochemical Society.

\section{Concluding Remarks}

In this paper, we reported the successful use of the rf-magnetron sputtering technique for the synthesis of $\mathrm{LiCoO}_{2}$ thin films with adequate texture and microstructure that allows it to be associated with a solid-state electrolyte thin films applied in rechargeable lithium microbatteries. For rf-sputtered $\mathrm{LiCoO}_{2}$ films, experimental results have shown the strong influence of the growth conditions on the preferential orientation, microstructure, and stoichiometry, which govern the electrochemical performance of cathode films in microbatteries. The (104) orientation facilitates larger Li-ion transport at the electrolyte/electrode interface and an increase in the capacity than that of the (003)-oriented thin film. Such preferred texture has been obtained using the annealing process as low as $500{ }^{\circ} \mathrm{C}$, which is a favorable condition for the device fabrication. Based on the optimization of parameters, good quality $\mathrm{LiCoO}_{2}$ films, from which more than half lithium ions can be extracted, delivered a specific capacity higher than $70 \mu \mathrm{Ah} \mathrm{cm}^{-2} \mu \mathrm{m}^{-1}$.

We focused attention on planar batteries. With this geometry, the areal energy density is limited. The thickness of the films is also limited to obtain good kinetics. 3D microbatteries are a promising design since it allows a scaling of the capacity by increasing the surface area of the 3D substrate, independent of film thickness. However, 3D TFBs have proven technologically very challenging to realize. The promise of a high capacity and stable microbattery has yet to be realized [111]. Nevertheless, efforts have already been made to model 3D thin film batteries for $\mathrm{LiCoO}_{2} /$ graphite materials taking into account the issues with inhomogeneous current distributions [112-114], inevitable with such complex geometries. Sputtering is one of the techniques used to construct such devices that are still at the research level $[115,116]$.

To date, lithium microbattery technology including $\mathrm{LiCoO}_{2}$ thin film cathode is almost mature and in the final form for actual applications. This class of power sources that belongs to the all-solid-state 
battery family including a lithium ion conductor (LIC) without undergoing liquid electrolyte leakage has the advantage of well-formed solid-electrolyte/electrode interfaces. Generally, LICs are safe with no risk of fire or explosion, thermally stable, and exhibit a wider electrochemical window than that of liquid electrolytes. However, the current density is quite low due to the poor ionic conductivity of the solid electrolyte such as LiPON. Development of a better electrolyte with the $\mathrm{Li}$ transport number close to unity such as perovskite-type oxides $\left((\mathrm{Li}, \mathrm{La}) \mathrm{TiO}_{3}\right)$, garnet-type frameworks $\left(\mathrm{Li}_{5} \mathrm{La}_{3} \mathrm{Ti}_{2} \mathrm{O}_{12}\right)$, or nitride-based glass ceramics are good candidates. Deposition of these materials by rf-sputtering should be the best technique in terms of film quality. Another prospective for the future is the development of thin films on flexible substrates for wearable electronics applications. The recent fabrication of a $\mathrm{Li} / \mathrm{LiBON} / \mathrm{LCO}$ microbattery demonstrates good electrochemical performance, i.e., capacity retention of $90 \%$ over 1000 cycles under heavy bending and twisting conditions.

Author Contributions: Conceptualization, C.M.J.; writing—original draft preparation, C.M.J.; writing-review and editing, A.M., O.M.H.

Funding: This research received no external funding.

Conflicts of Interest: The authors declare no conflict of interest.

\section{References}

1. Balkanski, M.; Julien, C.; Emery, J.Y. Integrable lithium solid-state microbatteries. J. Power Sources 1989, 26, 615-622. [CrossRef]

2. Bates, J.B.; Gruzalski, G.R.; Dudney, N.J.; Luck, C.F.; Yu, X.H.; Jones, S.D. Rechargeable thin-film lithium microbatteries. Solid State Technol. 1993, 36, 59-64.

3. Bates, J.B.; Dudney, N.J.; Gruzalski, G.R.; Zuhr, R.A.; Choudhury, A.; Luck, C.F.; Robertson, J.D. Fabrication and characterization of amorphous lithium electrolyte thin films and rechargeable thin-film batteries. J. Power Sources 1993, 43, 103-110. [CrossRef]

4. Bates, J.B.; Gruzalski, G.R.; Dudney, N.J.; Luck, C.F.; Yu, X.H. Rechargeable thin-film lithium microbatteries. Solid State Ion. 1994, 70-71, 619-628. [CrossRef]

5. Twentyman, J. Thin Film Batteries Set for Solid (State) Growth, Web Ref. (2017). Available online: https://internetofbusiness.com/thin-film-batteries-set-solid-state-growth (accessed on 3 November 2017).

6. Mizushima, K.; Jones, P.C.; Wiseman, P.J.; Goodenough, J.B. $\mathrm{Li}_{\mathrm{x}} \mathrm{CoO}_{2}(0<x<1)$ : A new cathode material for batteries of high energy density. Mater. Res. Bull. 1980, 15, 783-789. [CrossRef]

7. Ohzuku, T.; Ueda, A. Solid-state redox reactions of $\mathrm{LiCoO}_{2}(\mathrm{R}-3 \mathrm{~m})$ for 4 -volt secondary lithium cells. J. Electrochem. Soc. 1994, 141, 2972-2977. [CrossRef]

8. Yebka, B.; Julien, C. Lithium intercalation in sputtered $\mathrm{MoO}_{3}$ films. Ionics 1997, 3, 83-88. [CrossRef]

9. Julien, C. Solid State Batteries. In Handbook of Solid-State Electrochemistry; Gellings, P.J., Bouwmeester, H.J.M., Eds.; CRC Press: Roca Raton, FL, USA, 1997; Chapter 11; pp. 371-406.

10. Jayanth-Babu, K.; Jeevan-Kumar, P.; Hussain, O.M.; Julien, C.M. Influence of annealing temperature on microstructural and electrochemical properties of rf-sputtered $\mathrm{LiMn}_{2} \mathrm{O}_{4}$ film cathodes. J. Solid State Electrochem. 2012, 16, 3383-3390. [CrossRef]

11. Washizu, E.; Yamamoto, A.; Abe, Y.; Kawamura, M.; Sasaki, K. Optical and electrochromic properties of RF reactively sputtered $\mathrm{WO}_{3}$ films. Solid State Ion. 2003, 165, 175-180. [CrossRef]

12. Mazas-Brandariz, D.; Senaris-Rodriguez, M.A.; Castro-Garcia, S.; Camacho-Lopez, M.A.; Julien, C. Structural properties of $\mathrm{LiNi}_{1-\mathrm{y}} \mathrm{Co}_{\mathrm{y}} \mathrm{O}_{2}(0 \leq \mathrm{y} \leq 1)$ synthesized by wet chemistry via malic-acid assisted technique. Ionics 1999, 5, 345-350. [CrossRef]

13. Ohzuku, T.; Ueda, A.; Nagayama, M.; Iwakoshi, Y.; Komori, H. Comparative study of $\mathrm{LiCoO}_{2}, \mathrm{LiNi}_{1 / 2} \mathrm{Co}_{1 / 2} \mathrm{O}_{2}$ and $\mathrm{LiNiO}_{2}$ for 4 volt secondary lithium cells. Electrochim. Acta 1993, 38, 1159-1167. [CrossRef]

14. Stockhoff, T.; Gallasch, T.; Berkemeier, F.; Schmitz, G. Ion beam sputter-deposition of $\mathrm{LiCoO}_{2}$ films. Thin Solid Film. 2012, 520, 3668-3674. [CrossRef]

15. Markevich, E.; Salitra, G.; Aurbach, D. Influence of the PVdF binder on the stability of $\mathrm{LiCoO}_{2}$ electrodes. Electrochem. Commun. 2005, 7, 1298-1304. [CrossRef]

16. Ruffo, R.; Wessells, C.; Huggins, R.A.; Cui, Y. Electrochemical behavior of $\mathrm{LiCoO}_{2}$ as aqueous lithium-ion battery electrodes. Electrochem. Commun. 2009, 11, 247-249. [CrossRef] 
17. Shao-Horn, Y.; Levasseur, S.; Weill, F.; Delmas, C. Probing lithium vacancy ordering in O3 layered $\mathrm{Li}_{\mathrm{x}} \mathrm{CoO}_{2}$ $(x \approx 0.5)$ : An electron diffraction study. J. Electrochem. Soc. 2003, 150, A366-A373. [CrossRef]

18. Wang, G.J.; Qu, Q.T.; Wang, B.; Shi, Y.; Tian, S.; Wu, Y.P.; Holze, R. Electrochemical behavior of $\mathrm{LiCoO}_{2}$ in a saturated aqueous $\mathrm{Li}_{2} \mathrm{SO}_{4}$ solution. Electrochim. Acta 2009, 54, 1199-1203. [CrossRef]

19. Julien, C.M.; Mauger, A. Pulsed-laser deposited films for microbatteries. Coatings 2019, 9, 386. [CrossRef]

20. Sun, C.; Liu, J.; Gong, Y.; Wilkinson, D.P.; Zhang, J. Recent advances in all-solid-state rechargeable lithium batteries. Nano Energy 2017, 33, 363-386. [CrossRef]

21. Bates, J.B.; Dudney, N.J.; Neudecker, B.; Ueda, A.; Evans, C.D. Thin-film lithium and lithium ion batteries. Solid State Ion. 2000, 135, 33-45. [CrossRef]

22. Hayashi, M.; Takahashi, M.; Sakurai, Y. Preparation of positive $\mathrm{LiCoO}_{2}$ films by electron cyclotron resonance (ECR) plasma sputtering method and its application to all-solid-state thin-film lithium batteries. J. Power Sources 2007, 174, 990-995. [CrossRef]

23. Takahashi, M.; Hayashi, M.; Shodai, T. Characterization of all-solid-state secondary batteries with $\mathrm{LiCoO}_{2}$ thin films prepared by ECR sputtering as positive electrodes. J. Power Sources 2009, 189, 191-196. [CrossRef]

24. Navone, C.; Tintignac, S.; Pereira-Ramos, J.P.; Baddour-Hadjean, R.; Salot, R. Electrochemical behaviour of sputtered $c-\mathrm{V}_{2} \mathrm{O}_{5}$ and $\mathrm{LiCoO}_{2}$ thin films for solid state lithium microbatteries. Solid State Ion. 2011, 192, 343-346. [CrossRef]

25. Tintignac, S.; Baddour-Hadjean, R.; Pereira-Ramos, J.P.; Salot, R. High rate bias sputtered $\mathrm{LiCoO}_{2}$ thin films as positive electrode for all-solid-state lithium microbatteries. Electrochim. Acta 2014, 146, 472-476. [CrossRef]

26. Kim, H.-S.; Oh, Y.; Kang, K.H.; Kim, J.H.; Kim, J.; Yoon, C.S. Characterization of sputter-deposited $\mathrm{LiCoO}_{2}$ thin film grown on NASICON-type electrolyte for application in all-solid-state rechargeable lithium battery. Acs Appl. Mater. Interfaces 2017, 9, 16063-16070. [CrossRef] [PubMed]

27. Song, S.-W.; Choi, H.; Park, H.Y.; Park, G.B.; Lee, K.C.; Lee, H.-J. High rate induced structural changes in thin-film lithium batteries on flexible substrate. J. Power Sources 2010, 195, 8275-8279. [CrossRef]

28. Song, S.-W.; Lee, K.-C.; Park, H.-Y. High-performance flexible all-solid-state microbatteries based on solid electrolyte of lithium boron oxynitride. J. Power Sources 2016, 328, 311-317. [CrossRef]

29. Xiao, D.-L.; Tong, J.; Feng, Y.; Zhong, G.-H.; Li, W.-J.; Yang, C.-L. Improved performance of all-solid-state lithium batteries using LiPON electrolyte prepared with Li-rich sputtering target. Solid State Ion. 2018, 324, 202-206. [CrossRef]

30. Yoon, Y.S.; Lee, S.H.; Cho, S.B.; Nam, S.C. Influence of two-step heat treatment on sputtered lithium cobalt oxide thin films. J. Electrochem. Soc. 2011, 158, A1313-A1319. [CrossRef]

31. Yu, X.; Bates, J.B.; Jellison, G.E., Jr.; Hart, F.X. A stable thin-film electrolyte: Lithium phosphorus oxynitride. J. Electrochem. Soc. 1997, 144, 524-532. [CrossRef]

32. Xia, H.; Wang, H.L.; Xiao, W.; Lai, M.O.; Lu, L. Thin film Li electrolytes for all-solid-state micro-batteries. Int. J. Surface Sci. Eng. 2009, 3, 23-43. [CrossRef]

33. Bates, J.B.; Dudney, N.J.; Gruzalski, G.R.; Zuhr, R.A.; Choudhury, A.; Luck, C.F. Electrical properties of amorphous lithium electrolyte thin films. Solid State Ion. 1992, 53-56, 647-654.

34. Dudney, N.J. Solid-state thin-film rechargeable batteries. Mater. Sci. Eng. B 2005, 116, 245-249. [CrossRef]

35. Choi, C.H.; Cho, W.I.; Cho, B.W.; Kim, H.S.; Yoon, Y.S.; Tak, Y.S. Radio-frequency magnetron sputtering power effect on the ionic conductivities of LiPON films. Electrochem. Solid-State Lett. 2002, 5, A14-A17.

36. Hamon, Y.; Douard, A.; Sabary, F.; Marcel, C.; Vinatier, P.; Pecquenard, B.; Levasseur, A. Influence of sputtering conditions on ionic conductivity of LiPON thin films. Solid State Ion. 2006, 177, 257-261. [CrossRef]

37. Le Van-Jodin, L.; Claudel, A.; Secouard, C.; Sabary, F.; Barnes, J.P.; Martin, S. Role of the chemical composition and structure on the electrical properties of a solid state electrolyte: Case of a highly conductive LiPON. Electrochim. Acta 2018, 259, 742-751. [CrossRef]

38. Fleutot, B.; Pecquenard, B.; Martinez, H.; Letellier, M.; Levasseur, A. Investigation of the local structure of LiPON thin films to better understand the role of nitrogen on their performance. Solid State Ion. 2011, 186, 29-36. [CrossRef]

39. Wang, B.; Bates, J.B.; Hart, F.X.; Sales, B.C.; Zuhr, R.A.; Robertson, J.D. Characterization of thin-film rechargeable lithium batteries with lithium cobalt oxide cathodes. J. Electrochem. Soc. 1996, 143, 3203-3213. [CrossRef]

40. Fragnaud, P.; Brousse, T.; Schleich, D.M. Characterization of sprayed and sputter deposited $\mathrm{LiCoO}_{2}$ thin films for rechargeable microbatteries. J. Power Sources 1996, 63, 187-191. [CrossRef] 
41. Julien, C.; Camacho-Lopez, M.A.; Escobar-Alarcon, L.; Haro-Poniatowski, E. Fabrication of $\mathrm{LiCoO}_{2}$ thin-film cathodes for rechargeable lithium microbatteries. Mater. Chem. Phys. 2001, 68, 210-216. [CrossRef]

42. Zhang, H.; Demaray, R.E. Deposition of LiCoO2. U.S. Patent 8636876B2, 28 January 2014.

43. Kutbee, A.T.; Ghoneim, M.T.; Ahmad, S.M.; Hussain, M.M. Free-form flexible lithium-ion microbattery. IEEE Trans. Nanotechnol. 2016, 15, 402-408. [CrossRef]

44. Kutbee, A.T.; Bahabry, R.R.; Alamoudi, K.O.; Ghoneim, M.T.; Cordero, M.D.; Almuslem, A.S.; Gumus, A.; Diallo, E.M.; Nassar, J.M.; Hussain, A.M.; et al. Flexible and bio-compatible high-performance solid-state micro-battery for implantable orthodontic system. NPJ Flexible Electron. 2017, 1, 7.

45. Nam, S.C.; Park, H.Y.; Lim, Y.C.; Choi, K.G.; Lee, K.C.; Park, G.B.; Kim, J.B. Reserve battery having all solid state thin film battery. U.S. Patent 8389144, 5 March 2013.

46. Bates, J.B.; Dudney, N.J.; Neudecker, B.J.; Hart, F.X.; Jun, H.P.; Hackney, S.A. Preferred orientation of polycrystalline $\mathrm{LiCoO}_{2}$ films. J. Electrochem. Soc. 2000, 147, 59-70. [CrossRef]

47. Trask, J.; Anapolsky, A.; Cardozo, B.; Januar, E.; Kumar, L.; Miller, M.; Brown, R.; Bhardwaj, R. Optimization of $10-\mu \mathrm{m}$, sputtered, $\mathrm{LiCoO}_{2}$ cathodes to enable higher energy density solid state batteries. J. Power Sources 2017, 350, 56-64. [CrossRef]

48. Yoon, Y.; Park, C.; Kim, J.; Shin, D. Lattice orientation control of lithium cobalt oxide cathode film for all-solid-state thin film batteries. J. Power Sources 2013, 226, 186-190. [CrossRef]

49. Wei, G.; Haas, T.E.; Goldner, R.B. Thin films of lithium cobalt oxide. Solid State Ion. 1992, 58, 115-122. [CrossRef]

50. Dudney, N.J.; Jang, Y.I. Analysis of thin-film lithium batteries with cathodes of $50 \mathrm{~nm}$ to $4 \mu \mathrm{m}$ thick $\mathrm{LiCoO}_{2}$. J. Power Sources 2003, 119-121, 300-304.

51. Whitacre, J.F.; West, W.C.; Ratnakumar, B.V. The influence of target history and deposition geometry on RF magnetron sputtered $\mathrm{LiCoO}_{2}$ thin films. J. Power Sources 2001, 103, 134-139. [CrossRef]

52. Huang, L.; Mank, R.M.; Chen, Y. Method to improve LiCoO2 morphology in thin film batteries. U.S. Patent 9899661B2, 20 February 2018.

53. Hart, F.X.; Bates, J.B. Lattice model calculation of the strain energy density and other properties of crystalline $\mathrm{LiCoO}_{2}$. J. Appl. Phys. 1998, 83, 7560-7566. [CrossRef]

54. Jeevan-Kumar, P.; Jayanth-Babu, K.; Hussain, O.M. Characteristics of $\mathrm{HT}-\mathrm{LiCoO}_{2}$ cathode films synthesized by rf magnetron sputtering. AIP Conf. Proc. 2012, 1447, 779-780.

55. Ribeiro, J.F.; Sousa, R.; Silva, M.F.; Goncalves, L.M.; Silva, M.M.; Correia, J.H. Thin-film materials for solid-state rechargeable lithium batteries. Ecs Trans. 2013, 45, 139-142. [CrossRef]

56. Hayashi, M.; Takahashi, M.; Shodai, T. Preparation and electrochemical properties of pure lithium cobalt films by electron cyclotron resonance sputtering. J. Power Sources 2009, 189, 416-422. [CrossRef]

57. Zhang, J.-G.; Buckingham, S.; Johnson, L.G. Thin film battery. U.S. Patent 2004/0018424 A1, 29 January 2004.

58. Liao, C.L.; Lee, Y.H.; Fung, K.Z. The films growth and electrochemical properties of rf-sputtered $\mathrm{LiCoO}_{2}$ thin films. J. Alloy. Compd 2007, 436, 303-308. [CrossRef]

59. Ziebert, C.; Ketterer, B.; Rinke, M.; Adelhelm, C.; Ulrich, S.; Zum Gahr, K.-H.S.; Indris, S.; Schimmel, T. Constitution, microstructure, and battery performance of magnetron sputtered $\mathrm{Li}-\mathrm{Co}-\mathrm{O}$ thin film cathodes for lithium-ion batteries as a function of the working gas pressure. Surf. Coatings Technol. 2010, 205, 1589-1594.

60. Hukan-Yudar, H.; Pat, S.; Ozen, S.; Mohammadigharehbagh, R.; Musaoglu, C.; Korkmaz, S.; Pat, Z. Microstructural, surface and electrochemical properties of the nano layered $\mathrm{LiCoO}_{2}$ thin film cathode for $\mathrm{Li}$ ion battery. Vacuum 2018, 152, 248-251. [CrossRef]

61. Kusuril, Y.R.; Penki, T.; Nookala, M.; Morgen, P.; Gowravaram, M.R. Investigations on sputter deposited $\mathrm{LiCoO}_{2}$ thin films from powder target. Adv. Mater. Lett. 2013, 4, 615-620.

62. Joo, H.; Lee, H.; Cho, G.; Nam, T.; Huh, S.; Choi, B.; Jueong, H.; Noh, J. Influence of the metal-induced crystallization on the structural and electrochemical properties of sputtered $\mathrm{LiCoO}_{2}$ thin films. Thin Solid Film. 2017, 641, 53-58. [CrossRef]

63. Liao, C.-L.; Fung, K.-Z. Lithium cobalt oxide cathode film prepared by rf sputtering. J. Power Sources 2004, 128, 263-269. [CrossRef]

64. Kim, W.S. Characteristics of $\mathrm{LiCoO}_{2}$ thin film cathodes according to the annealing ambient for the post-annealing process. J. Power Sources 2004, 134, 103-109. [CrossRef] 
65. Noh, J.; Cho, G.; Jung, K.; Kang, W.; Ha, C.; Ahn, H.; Ahn, J.; Nam, T.; Kim, K. Fabrication of LiCoO 2 thin film cathodes by DC magnetron sputtering method. Mater. Res. Bull. 2012, 47, 2823-2826. [CrossRef]

66. Jung, K.-T.; Cho, G.-B.; Kim, K.-W.; Nam, T.-H.; Jeong, H.-M.; Huh, S.-C.; Chung, H.-S.; Noh, J.-P. Influence of the substrate texture on the structural and electrochemical properties of sputtered $\mathrm{LiCoO}_{2}$ thin films. Thin Solid Film. 2013, 546, 414-417. [CrossRef]

67. Xie, J.; Imanishi, N.; Hirano, A.; Matsumura, T.A.; Takeda, Y.; Yamamoto, O. Kinetics investigation of a preferential (104) plane oriented $\mathrm{LiCoO}_{2}$ thin film prepared by $\mathrm{RF}$ magnetron sputtering. Solid State Ion. 2007, 178, 1218-1224.

68. Pan, H.; Yang, Y. Effects of radio-frequency sputtering powers on the micro-structures and electrochemical properties of $\mathrm{LiCoO}_{2}$ thin film electrodes. J. Power Sources 2009, 189, 633-637. [CrossRef]

69. Bouwman, P.J.; Boukamp, B.A.; Bouwmeester, H.J.M.; Wondergem, H.J.; Notten, P.H.L. Structural analysis of submicrometer $\mathrm{LiCoO}_{2}$ films. J. Electrochem. Soc. 2001, 148, A311-A317. [CrossRef]

70. Liao, C.L.; Wu, M.T.; Yen, J.H.; Leu, I.C.; Fung, K.Z. Preparation of RF-sputtered lithium cobalt oxide nanorods by using porous anodic alumina (PAA) template. J. Alloys Compd. 2006, 414, 302-309. [CrossRef]

71. Cho, J.; Losego, M.D.; Zhang, H.G.; Kim, H.; Zuo, J.; Petrov, I.; Cahill, D.G.; Braun, P.V. Electrochemically tunable thermal conductivity of lithium cobalt oxide. Nat. Commun. 2014, 5, 4035. [CrossRef]

72. Lee, J.K.; Lee, S.J.; Baik, H.K.; Lee, H.Y.; Jang, S.K.; Lee, S.M. Substrate effect on the microstructure and electrochemical properties in the deposition of a thin film $\mathrm{LiCoO}_{2}$ electrode. Electrochem. Solid State Lett. 1999, 2, 512-515.

73. Jeevan-Kumar, P.; Jayanth-Babu, K.; Hussain, O.M.; Julien, C.M. RF-sputtered $\mathrm{LiCoO}_{2}$ thick films: Microstructure and electrochemical performance as cathodes in aqueous and non-aqueous microbatteries. Ionics 2013, 19, 421-428. [CrossRef]

74. Jeong, E.; Hong, C.; Tak, Y.; Nam, S.C.; Cho, S. Investigation of interfacial resistance between $\mathrm{LiCoO}_{2}$ cathode and LiPON electrolyte in the thin film battery. J. Power Sources 2006, 159, 223-226. [CrossRef]

75. Jeevan-Kumar, P.; Jayanth-Babu, K.; Hussain, O.M. Enhanced electrochemical properties of as grown $\mathrm{LiCoO}_{2}$ film cathodes: Influence of silicon substrate surface texturing. Mater. Chem. Phys. 2014, 143, 536-544. [CrossRef]

76. Zhu, X.; Guo, Z.; Du, G.; Zhang, P.; Liu, H.K. LiCoO 2 cathode thin film fabricated by RF sputtering for lithium ion microbatteries. Surf. Coatings Technol. 2010, 204, 1710-1714. [CrossRef]

77. Vieira, E.M.F.; Ribeiro, J.F.; Sousa, R.; Silva, M.M.; Dupont, L.; Gonçalves, L.M. Titanium oxide adhesion layer for high temperature annealed $\mathrm{Si}_{\mathrm{Si}} \mathrm{N}_{3} \mathrm{~N}_{4} / \mathrm{TiO} \times \mathrm{Pt} / \mathrm{LiCoO}_{2}$ battery structures. J. Electron. Mater. 2016, 45, 910-916. [CrossRef]

78. Hu, Q.; Li, R.; Zhang, X.; Gao, Q.; Wang, M.; Shi, H.; Xiao, Z.; Chu, P.K.; Huang, A. Lithium ion trapping mechanism of $\mathrm{SiO}_{2}$ in $\mathrm{LiCoO}_{2}$ based memristors. Sci. Rep. 2019, 9, 5081. [CrossRef] [PubMed]

79. Xie, J.; Imanishi, N.; Matsumura, T.; Hirano, A.; Takeda, Y.; Yamamoto, O. Orientation dependence of Li-ion diffusion kinetics in $\mathrm{LiCoO}_{2}$ thin films prepared by RF magnetron sputtering. Solid State Ion. 2008, 179, 362-370. [CrossRef]

80. Jeon, S.W.; Lim, J.K.; Lim, S.H.; Lee, S.M. As-deposited $\mathrm{LiCoO}_{2}$ thin film cathodes prepared by rf magnetron sputtering. Electrochim. Acta 2005, 51, 268-273. [CrossRef]

81. Pracharova, J.; Pridal, J.; Bludska, J.; Jakubec, I.; Vorlicek, V.; Malkova, Z.; Makris, T.D.; Giorgi, R.; Jastrabik, L. $\mathrm{LiCoO}_{2}$ thin-film cathodes grown by RF sputtering. J. Power Sources 2002, 108, 204-212. [CrossRef]

82. Rao, K.J.; Benqlilou-Moudden, H.; Couturier, G.; Vinatier, P.; Levasseur, A. Structure and electrical properties of sputtered lithium cobaltite thin films. Mater. Res. Bull. 2002, 37, 1353-1367. [CrossRef]

83. Benqlilou-Moudden, H.; Blondiaux, G.; Vinatier, P.; Levasseur, A. Amorphous lithium cobalt and nickel oxides thin films: Preparation and characterization by RBS and PIGE. Thin Solid Film. 1998, 333, 16-19. [CrossRef]

84. Park, Y.; Nam, S.C.; Lim, Y.C.; Choi, K.G.; Lee, K.C.; Park, G.B.; Park, H.; Cho, S.B. Influence of sputtering gas pressure on the $\mathrm{LiCoO}_{2}$ thin film cathode post-annealed at $400{ }^{\circ} \mathrm{C}$. Korean J. Chem. Eng. 2006, 23, 832-837.

85. Nimisha, C.S.; Mohan-Rao, G. Simulation and experimental study on compositional evolution of Li-Co in $\mathrm{LiCoO}_{2}$ thin films during sputter deposition. J. Appl. Phys. 2011, 109, 114910. [CrossRef]

86. Park, H.Y.; Lee, S.R.; Lee, Y.J.; Cho, B.W.; Cho, W.I. Bias sputtering and characterization of $\mathrm{LiCoO}_{2}$ thin film cathodes for thin film microbattery. Mater. Chem. Phys. 2005, 93, 70-78. [CrossRef] 
87. Tintignac, S.; Baddour-Hadjean, R.; Pereira-Ramos, J.-P.; Salot, R. High performance sputtered $\mathrm{LiCoO}_{2}$ thin films obtained at a moderate annealing treatment combined to a bias effect. Electrochim. Acta 2012, 60, 121-129. [CrossRef]

88. Tintignac, S.; Baddour-Hadjean, R.; Pereira-Ramos, J.P.; Salot, R. Electrochemical properties of high rate bias sputtered $\mathrm{LiCoO}_{2}$ thin films in liquid electrolyte. J. Power Sources 2014, 245, 76-82. [CrossRef]

89. Park, H.Y.; Nam, S.C.; Lim, Y.C.; Choi, K.G.; Lee, K.C.; Park, G.B.; Kim, J.B.; Kim, H.P.; Cho, S.B. LiCoO 2 thin film cathode fabrication by rapid thermal annealing for micro power sources. Electrochim. Acta 2007, 52, 2062-2067. [CrossRef]

90. Jeevan-Kumar, P.; Jayanth-Babu, K.; Hussain, O.M. Electrochemical performance of rf magnetron sputtered $\mathrm{LiCoO}_{2}$ thin film positive electrodes. AIP Conf. Proc. 2010, 1313, 224-226.

91. Xie, J.; Imanishi, N.; Zhang, T.; Hirano, A.; Takeda, Y.; Yamamoto, O.; Cao, G.S.; Zhao, X.B. Amorphous $\mathrm{LiCoO}_{2}$ thin films on $\mathrm{Li}_{1+x+y} \mathrm{Al}_{\mathrm{x}} \mathrm{Ti}_{2-x} \mathrm{Si}_{\mathrm{y}} \mathrm{P}_{3-y} \mathrm{O}_{12}$ prepared by radio frequency magnetron sputtering for all-solid-state Li-ion batteries. Electrochim. Acta 2010, 55, 5440-5445. [CrossRef]

92. Kim, H.K.; Yoon, Y.S. Characteristics of rapid-thermal annealed $\mathrm{LiCoO}_{2}$ cathode film for an all-solid-state thin film microbattery. J. Vac. Sci. Technol. A 2004, 22, 1182-1187. [CrossRef]

93. Julien, C.M.; Mauger, A.; Vijh, A.; Zaghib, K. Lithium Batteries: Science and Technology; Springer: Cham, Switzerland, 2016.

94. Polo da Fonseca, C.N.; Davalos, J.; Kleinke, M.; Fantini, M.C.A.; Gorenstein, A. Studies of $\mathrm{LiCoO}_{2}$ thin film cathodes produced by r.f. sputtering. J. Power Sources 1999, 81-82, 575-580.

95. Jang, Y.-I.; Dudney, N.J.; Blom, D.A.; Allard, L.F. Electrochemical and electron microscopic characterization on thin-film $\mathrm{LiCoO}_{2}$ cathodes under high-voltage cycling conditions. J. Power Sources 2003, 119-121, 295-299.

96. Noh, J.P.; Jung, K.T.; Kwon, T.H.; Cho, G.B.; Huh, S.C.; Choi, B.K.; Kim, K.W.; Nam, T.H. Microstructure and electrochemical properties of magnetron-sputtered $\mathrm{LiCoO}_{2} / \mathrm{LiNiO}_{2}$ multi-layer thin film electrode. Mater. Res. Bull. 2013, 48, 4993-4996. [CrossRef]

97. Bouwman, P.J.; Boukamp, B.A.; Bouwmeester, H.J.M.; Notten, P.H.L. Influence of diffusion plane orientation on electrochemical properties of thin film $\mathrm{LiCoO}_{2}$ electrodes. J. Electrochem. Soc. 2002, 140, A699-A709. [CrossRef]

98. Jacke, S.; Song, J.; Cherkashinin, G.; Dimesso, L.; Jaegermann, W. Investigation of the solid-state electrolyte/ cathode $\mathrm{LiPON} / \mathrm{LiCoO}_{2}$ interface by photoelectron spectroscopy. Ionics 2010, 16, 769-775. [CrossRef]

99. Matsushita, T.; Dokko, K.; Kanamura, K. Comparison of electrochemical behavior of $\mathrm{LiCoO}_{2}$ thin films prepared by sol-gel and sputtering processes. J. Electrochem. Soc. 2005, 152, A2229-A2237. [CrossRef]

100. Matsushita, T.; Dokko, K.; Kanamura, K. In situ FT-IR measurement for electrochemical oxidation of electrolyte with ethylene carbonate and diethyl carbonate on cathode active material used in rechargeable lithium batteries. J. Power Sources 2005, 146, 360-364. [CrossRef]

101. Matsui, M.; Dokko, K.; Kanamura, K. Dynamic behavior of surface film on $\mathrm{LiCoO}_{2}$ thin film electrode. J. Power Sources 2008, 177, 184-193. [CrossRef]

102. Matsui, M.; Dokko, K.; Akita, Y.; Munakata, H.; Kanamura, K. Surface layer formation of LiCoO2 thin film electrodes in no-aqueous electrolyte containing lithium bis(oxalate)borate. J. Power Sources 2012, 210, 60-66. [CrossRef]

103. Bai, L.; Xue, W.; Qin, H.; Li, Y.; Li, Y.; Sun, J. A novel dense $\mathrm{LiCoO}_{2}$ microcrystalline buffer layer on a cathode-electrolyte interface for all-solid-state lithium batteries prepared by the magnetron sputtering method. Electrochim. Acta 2019, 295, 677-683. [CrossRef]

104. Madhavi, S.; Subba-Rao, G.V.; Chowdari, B.V.R.; Li, S.F.Y. Effect of Cr dopant on the cathodic behavior of $\mathrm{LiCoO}_{2}$. Electrochim. Acta 2002, 48, 219-226. [CrossRef]

105. Zou, M.; Yoshio, M.; Gopukumar, S.; Yamaki, J. Performance of $\mathrm{LiM}_{0.05} \mathrm{Co}_{0.95} \mathrm{O}_{2}$ cathode materials in lithium rechargeable cells when cycled up to 4.5 V. Chem. Mater. 2005, 7, 1284-1286. [CrossRef]

106. Sivajee-Ganesh, K.; Purusottam-Reddy, B.; Jeevan-Kumar, P.; Hussain, O.M. Influence of Zr dopant on microstructural and electrochemical properties of $\mathrm{LiCoO}_{2}$ thin film cathodes by RF sputtering. J. Electroanal. Chem. 2018, 828, 71-79. [CrossRef]

107. Sivajee-Ganesh, K.; Purusottam-Reddy, B.; Hussain, O.M.; Mauger, A.; Julien, C.M. Influence of Ti and Zr dopants on the electrochemical performance of $\mathrm{LiCoO}_{2}$ film cathodes prepared by rf-magnetron sputtering. Mater. Sci. Eng. B 2016, 209, 30-36. [CrossRef] 
108. Needham, S.A.; Wang, G.X.; Liu, H.K.; Drozd, V.A.; Liu, R.S. Synthesis and electrochemical performance of doped $\mathrm{LiCoO}_{2}$ materials. J. Power Sources 2007, 174, 828-831. [CrossRef]

109. Sivajee-Ganesh, K.; Purusottam-Reddy, B.; Jeevan-Kumar, P.; Jayanth-Babu, K.; Rosaiah, O.; Hussain, O.M. Microstructural and electrochemical properties of $\mathrm{LiTi}_{\mathrm{y}} \mathrm{Co}_{1-\mathrm{y}} \mathrm{O}_{2}$ film cathodes prepared by rf- sputtering. J. Solid State Electrochem. 2015, 19, 3621-3627. [CrossRef]

110. Sivajee-Ganesh, K.; Purusottam-Reddy, B.; Jeevan-Kumar, P.; Jayanth-Babu, K.; Rosaiah, P.; Hussain, O.M. Structural and $\mathrm{AC}$ impedance analysis of rf sputtered Ti doped $\mathrm{LiCoO}_{2}$ thin films. Int. J. ChemTech Res. 2014, 6, 1974-1976.

111. Moitzheim, S.; Put, B.; Vereecken, P.M. Advances in 3D thin-film Li-ion batteries. Adv. Mater. Interfaces 2019. [CrossRef]

112. Zadin, V.; Kasemägi, H.; Aabloo, A.; Brandell, D. Modelling electrode material utilization in the trench model 3D-microbattery by finite element analysis. J. Power Sources 2010, 195, 6218-6224. [CrossRef]

113. Zadin, V.; Brandell, D.; Kasemägi, H.; Lellep, J.; Aabloo, A. Designing the 3D-microbattery grometry using the level-set method. J. Power Sources 2013, 244, 417-428. [CrossRef]

114. Grazioli, D.; Verners, O.; Zadin, V.; Brandell, D.; Simone, A. Electrochemical-mechanical modeling of solid polymer electrolytes: Impact of mechanical stresses on Li-ion battery performance. Electrochim. Acta 2019, 296, 1122-1141. [CrossRef]

115. Baggetto, L.; Niessen, R.A.H.; Roozeboom, F.; Notten, P.L.H. High energy density all-solid-state batteries: A challenging concept towards 3D integration. Adv. Func. Mater. 2008, 18, 1057-1066. [CrossRef]

116. Ruzmetov, D.; Oleshko, V.P.; Haney, P.M.; Lezec, H.J.; Karki, K.; Baloch, K.H.; Agrawal, A.K.; Avydov, A.V.; Krylyuk, S.; Liu, Y.; et al. Electrolyte stability determines scaling limits for solid-state 3D Li ion batteries. Nano Lett. 2012, 12, 505-511. [CrossRef]

(C) 2019 by the authors. Licensee MDPI, Basel, Switzerland. This article is an open access article distributed under the terms and conditions of the Creative Commons Attribution (CC BY) license (http://creativecommons.org/licenses/by/4.0/). 